\title{
Building Virtually Free Subject Area Expertise through Social Media: An Exploratory Study
}

\section{Brian K. Kooy}

\begin{abstract}
Central to the ongoing success of the liaison model is the need for liaison librarians to stay informed and up-to-date about recent developments in the subject areas of their assigned academic departments and programs. This article describes an exploratory study conducted to determine whether information obtained from the social media accounts of discipline-based scholarly associations can be used by liaison librarians as a no-cost expedient method of staying informed and up-to-date. The results of the study provide insights into the disciplines and associations that are using social media, the social media platforms that associations are using, the quantity and type of information that associations are posting, and the potential for liaisons to use the information as a way of staying current in their assigned subject areas.
\end{abstract}

Preliminary results of this study were presented as a poster session at the 2013 Annual Conference of the American Library Association, entitled "The Frugal Liaison Librarian: Building Virtually Free Subject Area Expertise Though Social Media."

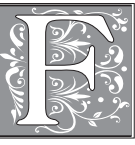

ormalized liaison programs, in which a group of librarians focus their work in a particular subject area and provide support for teaching, learning, and research to one or more academic departments, have been used by college and university libraries since at least the 1970 s. $^{1}$ The primary role of liaison librarians is to provide outreach between the library and the departments to which they are assigned by facilitating ongoing communication about the library, its services, and faculty and student resource needs. In addition, these librarians commonly deliver in-depth reference and research consultation services, provide course-integrated information literacy instruction, make purchasing decisions regarding print and electronic resources, and manage the collections of their assigned subject areas. ${ }^{2}$

Recent changes in teaching and research have prompted many libraries to reassess and, in some cases, restructure their liaison programs to address and accommodate new technologies, evolving research methods, advances in the way scholars communicate and disseminate their findings, greater collaboration between academic departments, and mandates from federal funding agencies. ${ }^{3}$ Some libraries, most notably the libraries at the University of Minnesota and Duke University, have created new guidelines for liaisons that position them to take a more proactive, engaged, and, in

Brian K. Kooy is the Middle East Studies, Philosophy, Political Science, and Religious Studies Librarian at the University Library at Georgia State University; e-mail: bkooy@gsu.edu. (C 2016 Brian K. Kooy, Attribution-NonCommercial (http://creativecommons.org/licenses/by-nc/3.0/) CC BY-NC. 
some cases, embedded approach to the departments, students, and faculty they serve. ${ }^{4}$ This new approach has required liaisons to assume new roles, develop new skills, and allocate more of their time to working directly with faculty research initiatives, digital scholarship, institutional repositories, data analysis, instructional design, scholarly communication, data management and curation, and copyright advisement, as well as providing assistance with grant applications and evidence of scholarly impact. ${ }^{5}$

Central to the ongoing success of both the traditional and new liaison model is the need for liaison librarians to stay informed about recent developments in the subject areas of their assigned academic departments and programs, as well as to continually hone and develop new skills, knowledge, and expertise to adapt to the constantly changing educational environment. Methods that liaisons have traditionally used to stay informed include monitoring and reading subject-specific journal literature; reading monographs; attending classes, workshops, and lectures; joining and participating in online communities via listservs; searching the Internet; joining discipline-based scholarly associations; and attending scholarly conferences. ${ }^{6}$ While these methods provide excellent opportunities for liaisons to learn about their subject areas, stay upto-date regarding cutting-edge research, and engage with scholars, they can be time consuming to execute on a regular basis and, in the case of association membership and conference attendance, expensive to maintain. The costs can be especially burdensome for liaisons who cover multiple subject areas. The costs are compounded for liaisons who are also required to maintain memberships in associations and attend conferences within the field of librarianship to satisfy service and professional development criteria for promotion and/or tenure decisions.

The idea for the current study arose from the author's experience as a subject librarian at Georgia State University in Atlanta, where he provides liaison services to the departments of Philosophy, Political Science, Religious Studies, and the Middle East Institute. Faced with limited time and resources to stay current in all four subject areas, the author searched for a less expensive and more efficient method of staying informed and up-to-date. Having used social media with success in the past to obtain information about library association activities and events, the author wondered whether social media could also be used to obtain information about developments in the subject areas of his assigned departments by monitoring the social media accounts of subject-specific scholarly associations. Specifically, the study sought to answer the following questions:

1. Are subject-specific scholarly associations using social media as a means to disseminate information to their members?

2. If associations are using social media, are some disciplines using the platforms more than others?

3. For those associations that are using social media, what specific kinds of information are the associations posting?

4. Could the information contained in the posts be used by liaisons to stay current in the developments of their assigned subject areas?

\section{Literature Review}

Very few studies have investigated the methods librarians use to stay informed and up-to-date. One of the most extensive studies is reported in Skye Hardesty's and Tammy Sugarman's “Academic Librarians, Professional Literature, and New Technologies: A Survey." 7 They report on a study of 707 academic librarians to determine their attitudes toward keeping current, the methods they used to stay informed, and whether technology was a help or a hindrance to doing so. Methods that respondents used most often to stay current included subscribing to listservs, reading journal and 
magazine articles, and attending in-person professional conferences. Other methods, in order of preference, included subscribing to table of contents e-mail alert services, attending virtual conferences, reading blogs, and using RSS aggregators. Technology was not considered a barrier to access, although some respondents were less than enthusiastic about the use of blogs and RSS feeds. Reasons cited included a lack of familiarity with the technology and the perception that blogs "are less prestigious" than print resources. ${ }^{8}$ Other respondents were more positive about their experiences, asserting that blogs and aggregators made it easier to collect information, were more up-to-date, and saved time. ${ }^{9}$ Barriers to staying up-to-date mentioned most often by respondents included not enough time to locate relevant information and not enough time to read the information once it was found.

In a more recent study, "Link Up the Sticks: Access and Barriers to Professional Development for Small and Rural Academic Librarians," Kaetrena Davis Kendrick, Echo Leaver, and Deborah Tritt report on a survey of 218 librarians at small and rural academic libraries to determine the methods they used to remain current and the barriers they encountered. ${ }^{10}$ Technology played a more significant role in this study in both learning about professional development opportunities and in accessing or attending such opportunities. Listservs, websites, blogs, and social networking sites were mentioned as methods used to discover professional development opportunities. Online access was cited as the preferred method of learning, followed by conferences, in-person classes, books, and on-the-job training. Although social media websites such as Facebook, LinkedIn, and Twitter were cited as methods of networking with other librarians to learn about professional development opportunities, social media was not specified as a means for staying informed of recent developments within librarianship or other subject disciplines. Barriers to staying informed included lack of personal funds for professional development, travel distance to conferences and workshops, lack of time, staffing issues, and budget cuts to institutional support.

A few studies have specifically addressed how liaison librarians or subject specialists stay current and maintain subject knowledge in their assigned disciplines. In "Spotlight on the Subject Knowledge of Chemistry Librarians: Results of a Survey," Christopher Hooper-Lane reports on a study of 35 chemistry librarians conducted to determine how they obtained and maintained subject knowledge. ${ }^{11}$ To obtain their knowledge, the majority of respondents held a degree in one of the science disciplines or, at the very least, had taken some college courses in chemistry. To maintain their knowledge, respondents spent the majority of their time monitoring electronic discussion lists, followed by networking with peers, reading articles in science and chemistry journals, surfing the web, and attending classes or lectures.

Erin M. Watson reports on how health science librarians obtain and maintain subject knowledge in two articles, "Subject Knowledge in the Health Sciences Library: An Online Survey of Canadian Academic Health Sciences Librarians" and "The Role of Subject Knowledge in Academic Health Sciences Libraries: An Online Survey of Librarians Working in the United States."12 In the Canadian study, the majority of respondents participated in professional organizations to gain and maintain knowledge, followed by surfing the web, reading articles in journals, subscribing to electronic newsletters, reading textbooks, attending university courses, and watching or listening to healthrelated television or radio shows. The results of the United States study, for the most part, mirrored the results of the Canadian study. Participating in professional associations was again the most widely used method of gaining and maintaining knowledge, followed by reading journal and magazine articles, surfing the web, subscribing to electronic newsletters, reading textbooks, and watching or listening to relevant television or radio shows. 
Two additional methods for keeping up-to-date that are relevant to the current study include membership in discipline-based scholarly associations and attendance at their affiliated conferences. ${ }^{13}$ In "The Benefits of Non-Library Professional Organization Membership for Liaison Librarians," Miranda Henry Bennett discusses a pilot program at the University of Houston Libraries in which an internally funded grant paid the membership fees for liaisons to join nonlibrary associations. ${ }^{14}$ Benefits of association membership reported by the participants included improved current awareness of research trends and issues in the disciplines and opportunities to interact with scholars as colleagues. A number of participants felt that association membership also resulted in improved relationships with the faculty members in the departments they serve, while others felt they increased their awareness of pedagogical issues within their assigned disciplines. Collection development benefits varied by participant; while some liaisons felt they became better informed of the latest publications in their field, others reported they obtained little relevant knowledge from the experience.

The benefits of liaison attendance at subject-specific conferences are addressed in two articles, "Meeting Our Users Where They Conference: A Texas A\&M Model to Support Librarian Attendance at Subject-Specific Conferences" by Rebecca Hankins, Pauline Melgoza, Christina Seeger, and Gary Wan and "The Dilemma for Academic Librarians with Collection Development Responsibilities: A Comparison of the Value of Attending Library Conferences Versus Academic Conferences" by Lucy Eleonore Lyons. ${ }^{15}$ In their article, Hankins et al. discuss a program at Texas A\&M University in which the library paid for librarians to attend subject conferences in the areas of education, agriculture, pharmacy, business, engineering, science, and the humanities. Participants in the program reported that they gained a better understanding of the research, reference, and information needs of their assigned departments. An additional benefit was the ability to meet and learn from faculty and scholars from other institutions. Obstacles included conferences that required association membership, a master's degree, or a PhD in the discipline to attend, and the high cost of registration fees. Interestingly, one librarian who did not participate in the program felt that reading association committee minutes, subject-specific blogs, and listservs "met the need for expert or collegial interaction, rather than traveling to a conference."16

Lyons' article, by contrast, compares publisher representation and the value of the programs offered at the annual meeting of the American Library Association (ALA) and the annual conference of the American Political Science Association (APSA) for librarians with subject-area collection development responsibilities. While she acknowledges that both types of conferences are important, she notes that insufficient time and/or funds forces many librarians that develop collections to choose between one or the other. Lyons observes from her experience that attending the academic APSA conference was more valuable to her duties as a subject selector in both the number of publishers that exhibited at the conference and the quality and relevance of the programs presented. As Lyons notes: "[A]t the academic conference, the subject selector is exposed not only to more of the relevant literature in the field, but also to the culture and world of that discipline. Information on programs, societies, and honors in the discipline is not present at the library conference, but is of importance to those who develop collections and act as liaisons to faculty and students in specific subject areas." ${ }^{17}$ Lyons concludes from her experience that, while library conferences are still valuable for peer interaction in the form of networking and skills development, subject selectors "who only attend library conferences risk being exposed to a very small proportion of the literature and publishers relevant to academic subjects, miss the benefits of interacting with scholars in the discipline, and miss an opportunity to become educated on the latest intellectual, methodological, and cultural developments in the subject field." ${ }^{18}$ 
In addition to the above studies, a number of non-research-based articles have been published that discuss the use of social networking sites and online communities for professional development and continuing education..$^{19}$ These articles offer advice, tips, and suggested tools and strategies to connect with other librarians to develop skills and expertise within the field of librarianship. No articles were located that provide quantitative or qualitative data regarding the effectiveness of using social media to stay informed and up-to-date. The current research adds to the literature by presenting the results of a study designed to determine whether information posted to the social media accounts of scholarly associations can be used by liaisons to remain informed and up-to-date in their assigned subject areas and disciplines. The article highlights the areas of a liaison librarian's job responsibilities that can benefit from using social media by providing examples of the types of information available via the associations' social media accounts.

\section{Methodology}

\section{Sample}

An analysis of messages made to select social media accounts of 50 scholarly associations was conducted to determine whether the information posted to the accounts would be useful to liaisons for staying informed and up-to-date in their assigned subject areas. Five associations were studied within each of the following ten areas: ${ }^{20}$

- $\quad$ Business \& Economics

- CTEMS: Computer Science, Technology, Engineering, Mathematics, and Statistics

- Education

- Health Sciences

- Humanities

- Interdisciplinary Studies

- Legal Studies

- Public Policy \& Administration

- Sciences

- $\quad$ Social Sciences

Associations were selected by reviewing the societies listed on the website of the American Council of Learned Societies, by noting the frequency with which the associations appeared on the curriculum vitae of teaching faculty at member institutions of the Association of American Universities, and by holding discussions with subject librarians and teaching faculty at Georgia State University.

For the purposes of the study, a scholarly association was defined as a not-for-profit voluntary organization that exists to promote an academic discipline, subdiscipline, or field of study by encouraging and providing the means for research to be exchanged and disseminated, usually through meetings, conferences, and the publication of its proceedings or journal(s). ${ }^{21}$ Discipline-based professional associations, defined as voluntary associations whose primary mission is to provide and enforce standards of professional education, ethics, and practice, were also included, as long as the associations encourage research and provide a means for that research to be exchanged and disseminated.

Facebook, LinkedIn, Twitter, and YouTube were selected as the social media sites from which messages were analyzed for the study. These platforms were chosen after reviewing the websites of the sampled associations and determining that the majority of associations maintained accounts with these sites over other social media platforms. These sites were also ranked as having received the most user visits per month, as compared with other social media platforms, by Quantcast, a technology company 
that specializes in real-time measurement of website traffic. ${ }^{22}$ Association social media accounts were identified by searching for and following links located on the association websites; using the search functions embedded within Facebook, LinkedIn, Twitter, and YouTube; and searching the Internet. For associations that maintain multiple accounts on any one social media platform, only the primary account was included in the study, as determined by information found on the association website or the description provided on the social media account. Since one question the study sought to answer was the extent to which social media is or is not being used by scholarly associations, maintaining active social media accounts was not a prerequisite for an association to be included in the study.

\section{Data Collection \& Analysis}

A data collection form suitable for hand coding was created to tally and record information. Messages posted to the association social media accounts during the time period starting September 1, 2012, and ending December 31, 2012, were chosen as the sample to be analyzed. Manual coding of the posts began on January 1, 2013, and ended on January 31, 2014..$^{23}$ A separate form was completed for each of the 50 associations studied. Fields in the first part of the form recorded information about the association and the association website, including the website URL, the subject area of the association, and the number and type of social media accounts maintained. Fields in the second part of the form recorded information about the association's use of the four social media studied, including the number of "likes," "followers," "members," or "subscribers," the date the account was created, whether membership was open or closed, and the number and types of messages posted to active accounts. Messages were analyzed and coded based on whether the information would be beneficial to a liaison librarian with respect to the following categories:

- Subject Knowledge: Information that would increase a liaison librarian's knowledge of the subject or discipline.

- Collection Development: Information that would help a liaison become familiar with new and relevant books, periodicals, and databases.

- Research Trends: Information that would increase a liaison's knowledge of current research in the discipline.

- Technology: Information that would increase a liaison's knowledge of new and important technologies within the discipline.

- Pedagogy: Information that would help a liaison understand current, new, or innovative pedagogical practices in the discipline.

- Association Information: Information that would keep a liaison informed of association activities, news, and events.

- Current Events: Contemporary issues or events that might affect the discipline. These coding categories were chosen after a review of liaison librarian job descriptions and responsibilities located on the Internet, as well as through the author's personal experience.

The unit of analysis for the study was an individual "post" made to an association's social media account. A "post," or "tweet" as it is called in Twitter, was defined as a single content entry made to a social media account. Facebook, LinkedIn, and Twitter posts could contain text, images, or hyperlinks to external content. Facebook posts could also include embedded videos. ${ }^{24}$ A post to a YouTube Channel was defined as an individual video uploaded by an association. Hyperlinks included as part of a post or tweet were followed to determine the content of the linked information and into which of the seven categories the content should be coded. Only official association posts were coded for Facebook Pages and YouTube Channels. Follower and subscriber 
posts or comments were not coded, since these were considered irrelevant for keeping a liaison up-to-date. Both association and member posts were coded for Facebook Groups, Twitter, and LinkedIn Groups, including retweeted (shared) messages in the case of Twitter, as these media types encourage discussion between their followers and Group members. Posts were coded to only one category, following the advice of Ryan K. Boettger and Laura A. Palmer that "categorizing a single unit of data under multiple categories can lead to false inferences and can impede accurate statistical analysis." 25 Posts that could not be coded into one of the seven categories were assigned a code of "Other." Multiple posts on the same topic, such as duplicate announcements of the same conference or of the same call for papers, were coded only once. Messages written in languages other than English were excluded from the study. Collected information was entered into a spreadsheet for analysis. Calculations were made for the number of total posts, the number of relevant posts, and the number of posts for each of the seven categories under review. Some categories were divided into additional subcategories for increased specificity.

\section{Results and Discussion}

The results of the study indicate that the majority of the sampled associations used social media to communicate, disseminate information, and engage with their users during the review period. Of the 50 associations sampled, 47 associations (94\%) maintained an account with at least one of the social media platforms included in the study: Facebook, LinkedIn, Twitter, or YouTube. Of these, 26 associations (55\%) maintained accounts with all four of the social media platforms, 12 associations (26\%) maintained accounts with three of the platforms, 6 associations (13\%) maintained accounts with two of the platforms, and 3 associations (6\%) maintained an account with one of the platforms. Three associations did not maintain accounts with any of the social media platforms studied (the Latin American Studies Association, Law and Society Association, and Public Management Research Association). Science associations maintained the most accounts ( $n=20$, meaning that all five of the sampled science associations maintained an account with each of the four social media platforms included in the study), followed by CTEMS, Education, and Health Science associations ( $n=19)$, Social Science associations $(n=18)$, Business \& Economics associations $(n=15)$, Humanities and Public Policy \& Administration associations $(n=14)$, Legal Studies associations $(n=10)$, and Interdisciplinary Studies associations $(n=7)$. See appendix A for a list of the sampled associations (arranged alphabetically by subject area) and the social media accounts that each association maintained during the time period of the study.

Of the 47 associations maintaining an account with at least one of the social media platforms, 46 (98\%) had a Facebook account, 42 (89\%) had a Twitter account, 34 (72\%) had a LinkedIn account, and $33(70 \%)$ had a YouTube Channel. Of the 46 Facebook accounts, 43 associations had a Facebook Page, while 3 associations had a Facebook Group. All Facebook Pages could be "liked" by anyone with a Facebook account, meaning that approval was not necessary to join and follow the Pages. Of the associations with a Facebook Group, two were "auto-join," meaning that approval by the Group manager was not necessary (Groups maintained by the Society for Literature, Science, and the Arts and American Society of Criminology), and one was "request to join," meaning that membership required approval by the Group administrator (the Association for Asian American Studies). Once approved, posts could be read, analyzed, and coded. Of the associations with LinkedIn accounts, 33 associations had a Group Page on which members could post messages, while one association (the American Bar Association) had a Company Page on which only the association could post. Ten of the 33 LinkedIn Groups were auto-join, while 23 Groups were request-to-join. Of 
the latter, 16 of the author's requests were approved, while seven requests were not approved (the American Academy of Forensic Sciences, American Chemical Society, American Finance Association, American Physiological Society, American Society for Microbiology, American Society of Civil Engineers, and IEEE: Institute of Electrical and Electronics Engineers). Of the seven requests that were not approved, one association's Group posts were able to be read without approval (the American Academy of Forensic Sciences). These posts were coded and included in the results. Posts for the Groups that were not approved and not able to be viewed could not be coded.

A total of 15,204 posts were made by the sampled associations to their combined social media accounts. The majority of these posts were made to Twitter, followed by LinkedIn, Facebook, and YouTube. Of the 15,204 total posts, 8,935 posts (58.8\%) were deemed to be "relevant" (that is to say, able to be coded to at least one of the seven categories of the study). Of the 8,935 relevant posts, once again the majority were made to Twitter, followed by LinkedIn, Facebook, and YouTube. Comparing the percentage of relevant to total posts, 65.4 percent of Facebook posts, 72.0 percent of LinkedIn posts, 53.6 percent of Twitter posts, and 98.9 percent of YouTube posts were deemed to be relevant. Thus, while Twitter was the most heavily used platform, it was also the platform to which the majority of nonrelevant messages were posted. Nonrelevant posts to all platforms included duplicate messages on the same topic or issue, social interaction between account administrators and account members, reminder messages of upcoming deadlines, inspirational messages of encouragement, and various other exchanges that could not be coded to one of the seven categories of the study. See figure 1 for a comparison of the number of total to relevant posts made to each of the social media platforms.

As shown in figure 2, most of the messages determined to be relevant were posted by Science associations, followed by associations in the fields of CTEMS, Health Science, Social Science, Humanities, Education, Public Policy \& Administration, Legal Studies, Business \& Economics, and Interdisciplinary Studies (see table 1 for a breakdown of the number of relevant posts made to each of the social media platforms by subject area). The five most active associations across all four social media platforms were the American Geophysical Union (10.8\%, n=966), American Medical Association (7.5\%, n=667), American Society of Civil Engineers (6.6\%, n=591), American Physical Society (5.5\%, n=494), and American Psychological Association (5.3\%, n=475). The five least active associations, of those associations that maintained at least one social

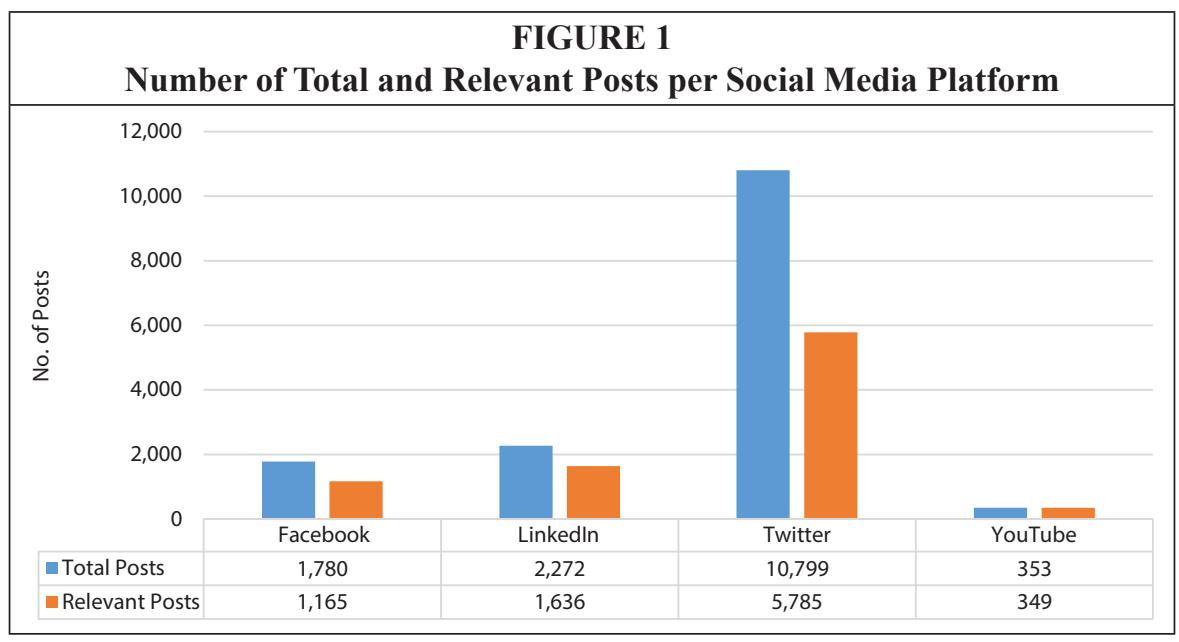




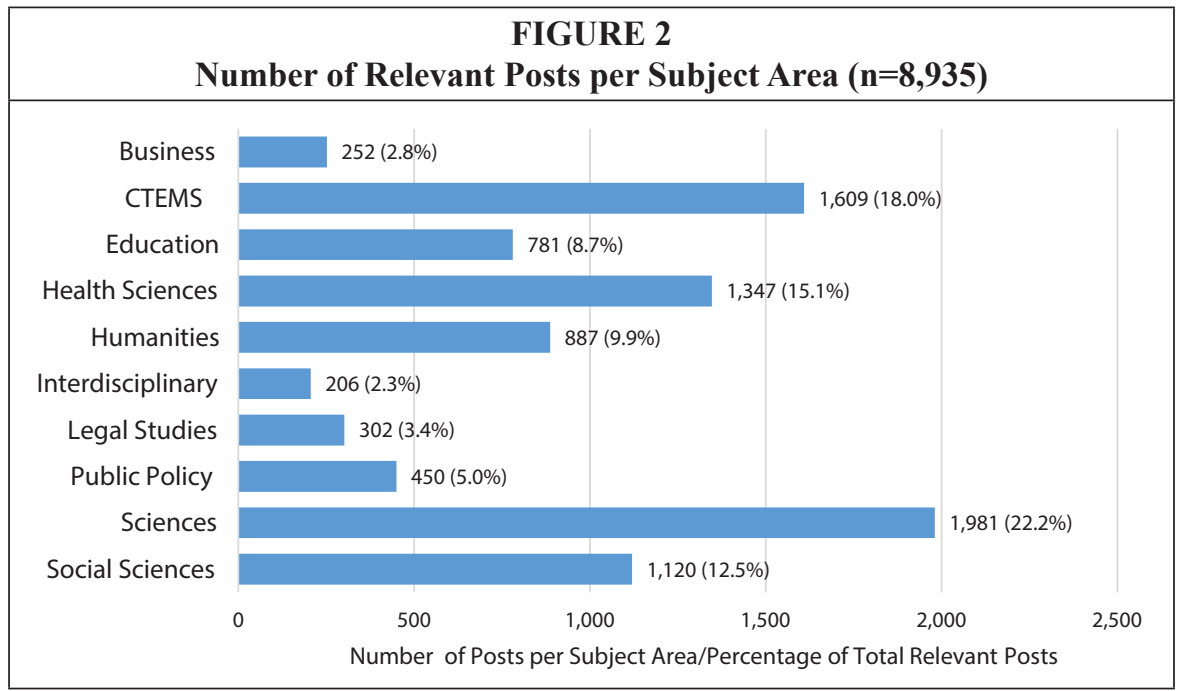

media account, were the Urban Affairs Association (0.17\%, n=15), American Academy of Religion $(0.15 \%, n=13)$, American Academy of Forensic Sciences $(0.15 \%, n=13)$, American Association for Budget and Program Analysis $(0.11 \%, \mathrm{n}=10)$, and Society for Literature, Science, and the Arts, with no relevant posts during the review period. The average number of relevant posts by associations with at least one social media account was 190. The median number of relevant posts by associations with at least one social media account was 133, with a minimum of zero and a maximum of 966 . By social media platform, the average number of relevant posts per association to Facebook was 25; to LinkedIn, 47; to Twitter, 138; and to YouTube, 11. See appendix B for a detailed breakdown of the number of relevant posts made by each of the associations to their social media accounts.

\begin{tabular}{|l|c|c|c|c|c|}
\hline \multicolumn{7}{|c|}{ TABLE 1 } \\
Number of Relevant Posts per Social Media Platform by Subject Area \\
\hline Subject Area & Facebook & LinkedIn & Twitter & YouTube & $\begin{array}{c}\text { Total Posts by } \\
\text { Subject Area }\end{array}$ \\
\hline Business & 30 & 33 & 185 & 4 & $\mathbf{2 5 2}$ \\
\hline CTEMS & 83 & 137 & 1,380 & 9 & $\mathbf{1 , 6 0 9}$ \\
\hline Education & 73 & 74 & 587 & 47 & $\mathbf{7 8 1}$ \\
\hline Health Sciences & 123 & 456 & 715 & 53 & $\mathbf{1 , 3 4 7}$ \\
\hline Humanities & 64 & 30 & 792 & 1 & $\mathbf{8 8 7}$ \\
\hline Interdisciplinary & 151 & 0 & 55 & 0 & $\mathbf{2 0 6}$ \\
\hline Legal Studies & 38 & 182 & 82 & 0 & $\mathbf{3 0 2}$ \\
\hline Public Policy & 44 & 90 & 306 & 10 & $\mathbf{4 5 0}$ \\
\hline Sciences & 441 & 366 & 969 & 205 & $\mathbf{1 , 9 8 1}$ \\
\hline Social Sciences & 118 & 268 & 714 & 20 & $\mathbf{1 , 1 2 0}$ \\
\hline $\begin{array}{l}\text { Total Posts by Social } \\
\text { Media Platform }\end{array}$ & $\mathbf{1 , 1 6 5}$ & $\mathbf{1 , 6 3 6}$ & $\mathbf{5 , 7 8 5}$ & $\mathbf{3 4 9}$ & $\mathbf{8 , 9 3 5}$ \\
\hline
\end{tabular}


As shown in figure 3, most of the messages posted by associations were coded to the Subject Knowledge category, followed by Research Trends, Current Events, Association Information, Collection Development, Pedagogy, and Technology (see table 2 for a breakdown of the number of relevant posts coded to each of the seven categories by subject area). In regard to Subject Knowledge, as shown in figure 4, CTEMS associations posted the highest number of messages coded to the category, followed by associations in the fields of Science, Health Science, Social Science, Humanities, Education, Public Policy \& Administration, Legal Studies, Interdisciplinary Studies, and Business \& Economics. Associations posting the most information relevant to improving a liaison's subject knowledge included the American Society of Civil Engineers $(13.7 \%$, $\mathrm{n}=522)$, IEEE: Institute of Electrical and Electronics Engineers $(8.7 \%, n=330)$, American Geophysical Union (8.0\%, n=303), American Medical Association (7.2\%, n=275), and American Physical Society $(5.0 \%, n=192)$. See appendix $C$ for a breakdown of the number of posts made by the sampled associations to each of the coded categories.

Looking beyond the numbers, the high volume of messages coded as Subject Knowledge may be slightly inflated due to the broad interpretation used to define the category. Examples of relevant posts to the category included links to print and video lectures, interviews with scholars and practitioners, announcements of subject-area award recipients, topic-specific podcasts, image collections, continuing education webinars, and $\mathrm{K}-12$ lesson plans. The majority of these posts included information that liaisons could potentially use to stay informed and up-to-date. Some of the messages posted to Facebook and Twitter, however, contained only brief notices of important dates and historical events or news items relevant to a particular subject area or discipline. While information of this type might be helpful to liaisons with little or no subject expertise in their assigned disciplines, it would not provide the depth of knowledge necessary to gain and maintain familiarity of a subject on anything more than a superficial level.

Overall, posts coded to the Research Trends category were found to have the most potential for keeping liaisons up-to-date on current and emerging research trends and for gaining and maintaining knowledge about a subject. As shown in figure 5,

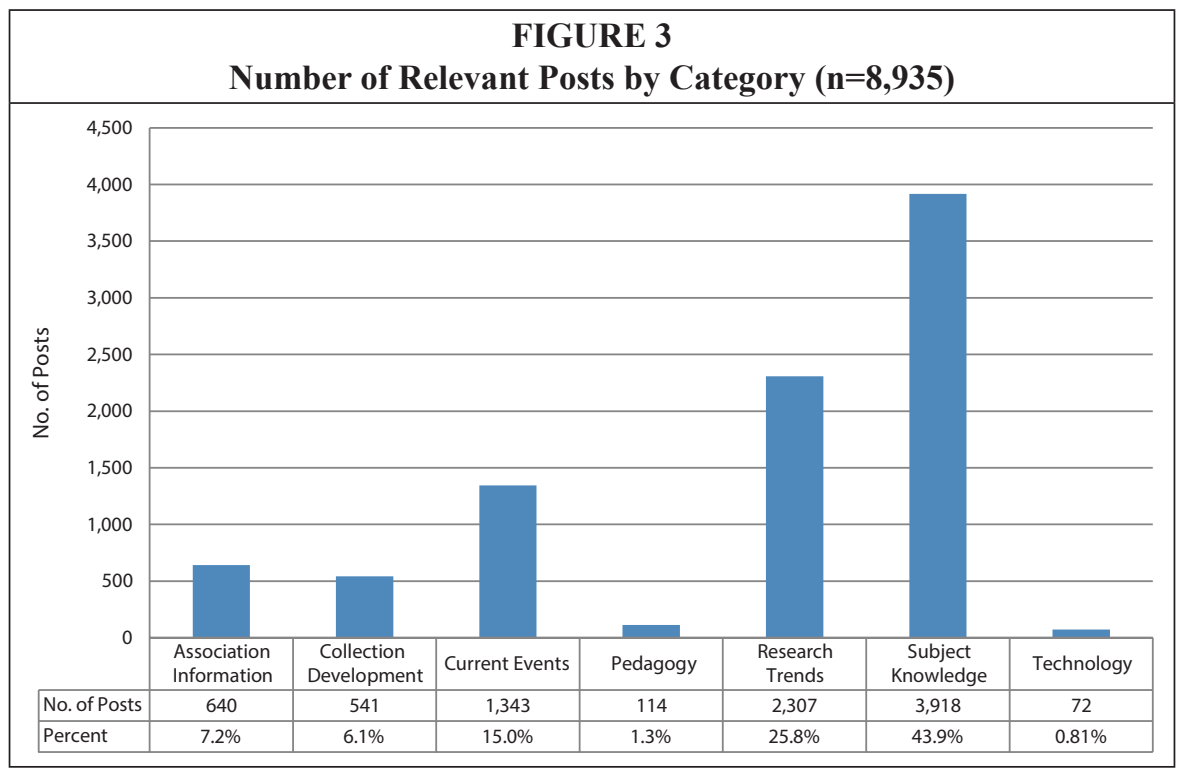




\section{TABLE 2}

Number of Relevant Posts per Category by Subject Area

\begin{tabular}{|l|c|c|c|c|c|c|c|c|}
\hline Subject Area & $\begin{array}{c}\text { Association } \\
\text { Information }\end{array}$ & $\begin{array}{c}\text { Collection } \\
\text { Development }\end{array}$ & $\begin{array}{c}\text { Current } \\
\text { Events }\end{array}$ & Pedagogy & $\begin{array}{c}\text { Research } \\
\text { Trends }\end{array}$ & $\begin{array}{c}\text { Subject } \\
\text { Knowledge }\end{array}$ & Technology & $\begin{array}{c}\text { Total Posts } \\
\text { by Subject } \\
\text { Area }\end{array}$ \\
\hline Business & 41 & 10 & 10 & 4 & 169 & 17 & 1 & $\mathbf{2 5 2}$ \\
\hline CTEMS & 99 & 38 & 115 & 29 & 127 & 1,195 & 6 & $\mathbf{1 , 6 0 9}$ \\
\hline Education & 58 & 102 & 99 & 15 & 127 & 360 & 20 & $\mathbf{7 8 1}$ \\
\hline Health Sciences & 104 & 22 & 381 & 6 & 190 & 634 & 10 & $\mathbf{1 , 3 4 7}$ \\
\hline Humanities & 99 & 210 & 29 & 23 & 255 & 266 & 5 & $\mathbf{8 8 7}$ \\
\hline Interdisciplinary & 28 & 19 & 54 & 2 & 64 & 39 & 0 & $\mathbf{2 0 6}$ \\
\hline Legal Studies & 15 & 15 & 155 & 0 & 13 & 103 & 1 & $\mathbf{3 0 2}$ \\
\hline Public Policy & 37 & 12 & 61 & 4 & 149 & 186 & 1 & $\mathbf{4 5 0}$ \\
\hline Sciences & 68 & 21 & 239 & 18 & 821 & 799 & 15 & $\mathbf{1 , 9 8 1}$ \\
\hline Social Sciences & 91 & 92 & 200 & 13 & 392 & 319 & 13 & $\mathbf{1 , 1 2 0}$ \\
\hline $\begin{array}{l}\text { Total Posts by } \\
\text { Category }\end{array}$ & $\mathbf{6 4 0}$ & $\mathbf{5 4 1}$ & $\mathbf{1 , 3 4 3}$ & $\mathbf{1 1 4}$ & $\mathbf{2 , 3 0 7}$ & $\mathbf{3 , 9 1 8}$ & $\mathbf{7 2}$ & $\mathbf{8 , 9 3 5}$ \\
\hline
\end{tabular}

Science associations posted the most information relevant to following or keeping up with current and emerging research, followed by associations in the fields of Social Science, Humanities, Health Science, Business \& Economics, Public Policy \& Administration, CTEMS and Education, Interdisciplinary Studies, and Legal Studies. Associations posting the most information coded to the Research Trends category included the American Geophysical Union (17.9\%, n=414), American Physical Society $(10.9 \%$, $\mathrm{n}=252)$, American Psychological Association (10.2\%, n=235), American Musicological Society $(8.1 \%, \mathrm{n}=188)$, and Association for Public Policy Analysis \& Management $(6.0 \%$, $\mathrm{n}=138$ ). Examples of research-related posts included links to and discussions about recent research studies $(63.3 \%, n=1,461)$, calls for papers on specific topics to be presented at conferences or published in special issues of journals $(12.6 \%, n=291)$, videos and transcripts of conference presentations $(10.1 \%, \mathrm{n}=234)$, job posts as indicators of trends or changes of focus within a subject area or discipline $(9.1 \%, \mathrm{n}=209)$, conference reports highlighting recent and cutting-edge research $(3.4 \%, \mathrm{n}=79)$, and discussions about ideas for future research $(1.4 \%, n=33)$.

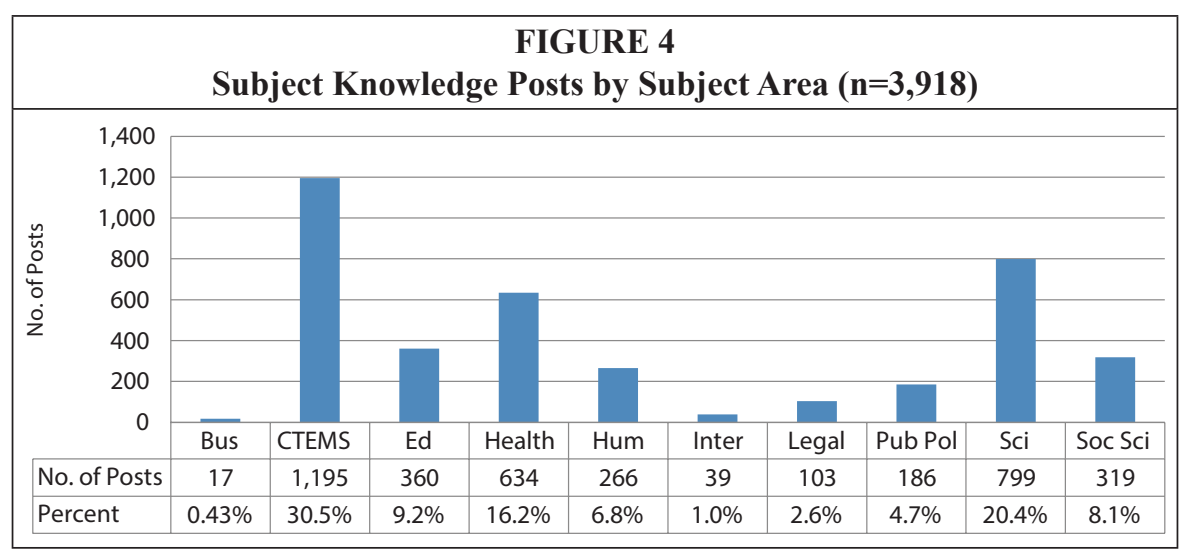




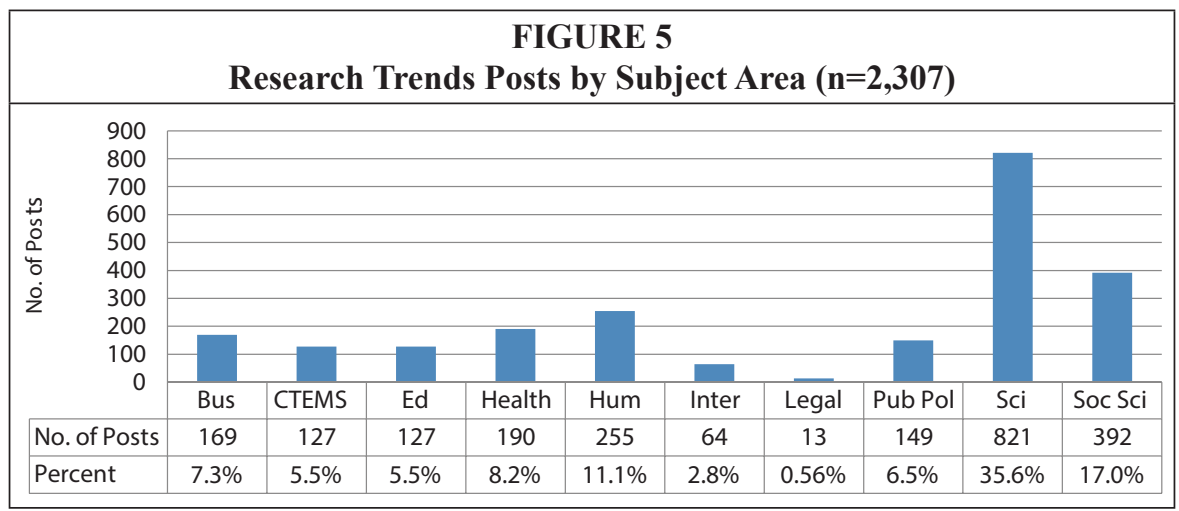

Somewhat surprising was the relatively large number of current events-related posts and how important the events were to some of the disciplines in regard to ideas for future research and the funding of grants, as determined by the amount of discussion about the events on the associations' Twitter and LinkedIn accounts. As seen in figure 6, Health Science associations posted the most messages coded to the Current Events category, followed by associations in the fields of Science, Social Science, Legal Studies, CTEMS, Education, Public Policy \& Administration, Interdisciplinary Studies, Humanities, and Business \& Economics. Associations posting the most current events-related information included the American Medical Association $(20.3 \%, \mathrm{n}=272)$, American Geophysical Union (13.5\%, n=181), American Society of Criminology (8.9\%, $n=120)$, American Psychological Association (8.4\%, n=113), and American Anthropological Association $(3.8 \%, n=51)$. Posts determined to be relevant included links to articles in online newspapers, magazines, blogs, and articles posted to association websites. Events mentioned most often included the Sandy Hook Elementary School shooting in Connecticut, Hurricane Sandy, the 2012 presidential election, the federal budget sequestration, specific legal cases, and the K-12 Common Core Standards.

Less surprising was the number of posts coded to the Association Information category, promoting association-related activities, news, and events. By subject area, as shown in figure 7, Health Science associations posted the most information relevant to keeping a liaison informed of association news and events, followed by associations in the fields of CTEMS, Humanities, Social Science, Science, Education, Business \& Economics, Public Policy \& Administration, Interdisciplinary Studies, and Legal Studies.

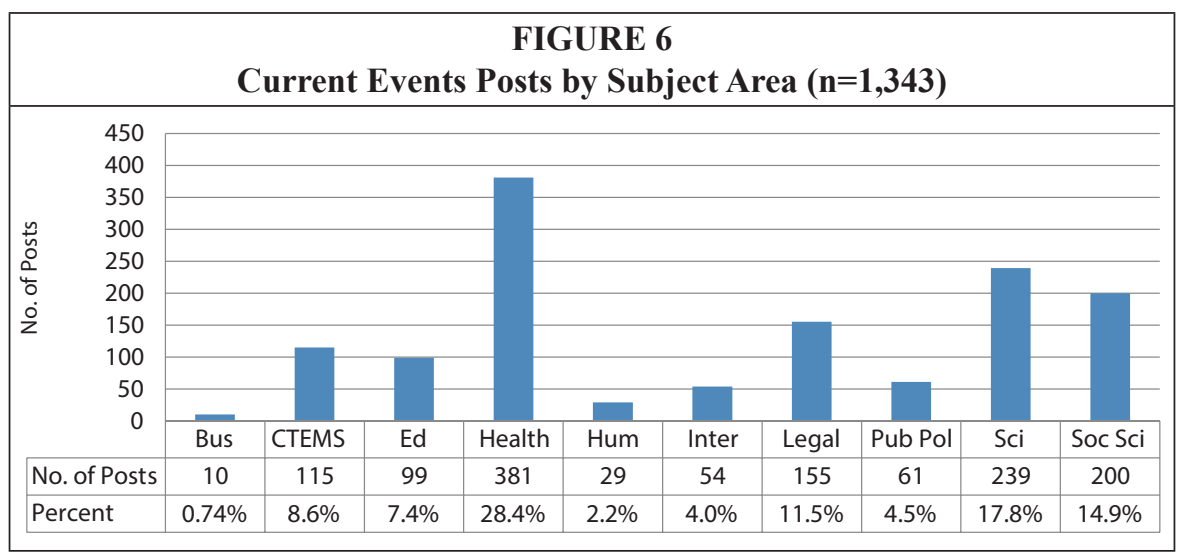




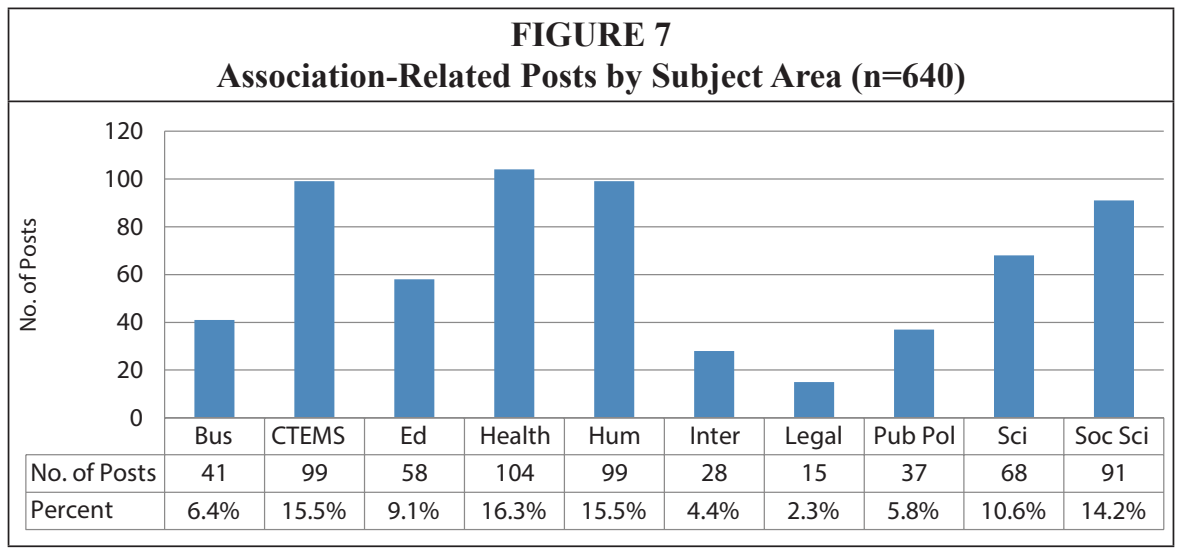

By association, the American Medical Association posted the most information coded to the Association Information category $(8.9 \%, n=57)$, followed by the American Geophysical Union and American Statistical Association (7.0\%, $\mathrm{n}=45)$, American Musicological Society $(6.6 \%, n=42)$, and American Anthropological Association $(4.5 \%, n=29)$. Relevant information included messages about subject-specific conferences, grants, scholarships, association award winners, the election of officers, and links to publicly accessible online newsletters.

The social media platforms were less effective for learning about new books, journals, and databases, as evidenced by the relatively low number of posts coded to the Collection Development category. Overall, there were only 541 posts determined to be relevant, the majority of which were made by six associations: the American Musicological Society (25.3\%, n=137), National Council of Teachers of English $(12.0 \%$, $\mathrm{n}=65)$, College Art Association (11.6\%, n=63), National Communication Association $(8.7 \%, n=47)$, Society of Health and Physical Educators $(5.5 \%, n=30)$, and American Anthropological Association $(4.3 \%, n=23)$. Of the remaining 41 associations that used social media, three associations made 11-20 collection development-related posts, 31 associations made 1-10 posts, and seven associations did not post any information related to collection development/materials or issues. By subject area, as shown in figure 8 , Humanities associations posted the most information coded to the Collection Development category, followed by associations in the fields of Education, Social Science, CTEMS, Health Science, Science, Interdisciplinary Studies, Legal Studies, Public Policy \& Administration, and Business \& Economics. Examples of relevant posts included announcements and reviews of new and important books $(66.7 \%, \mathrm{n}=361)$,

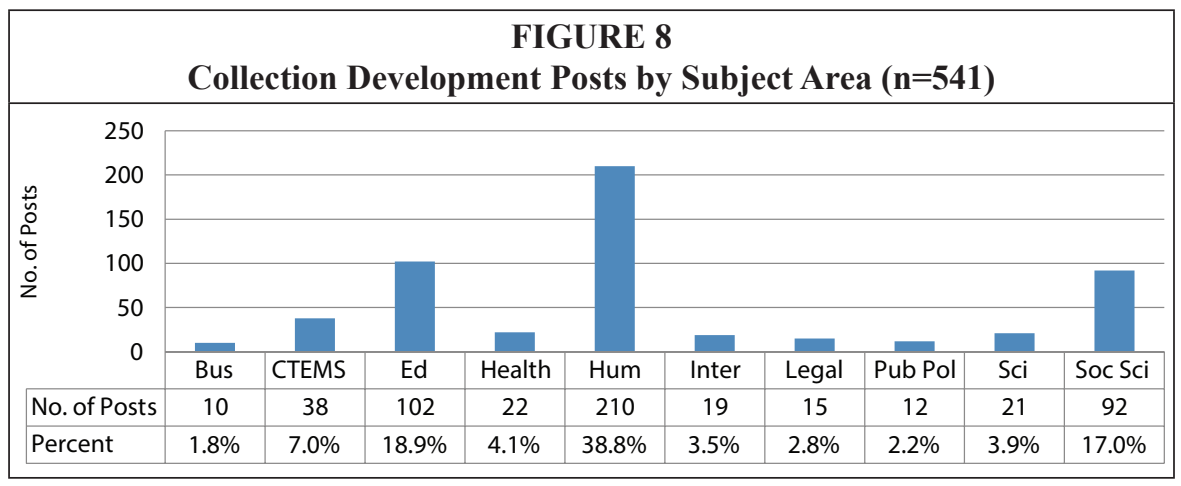




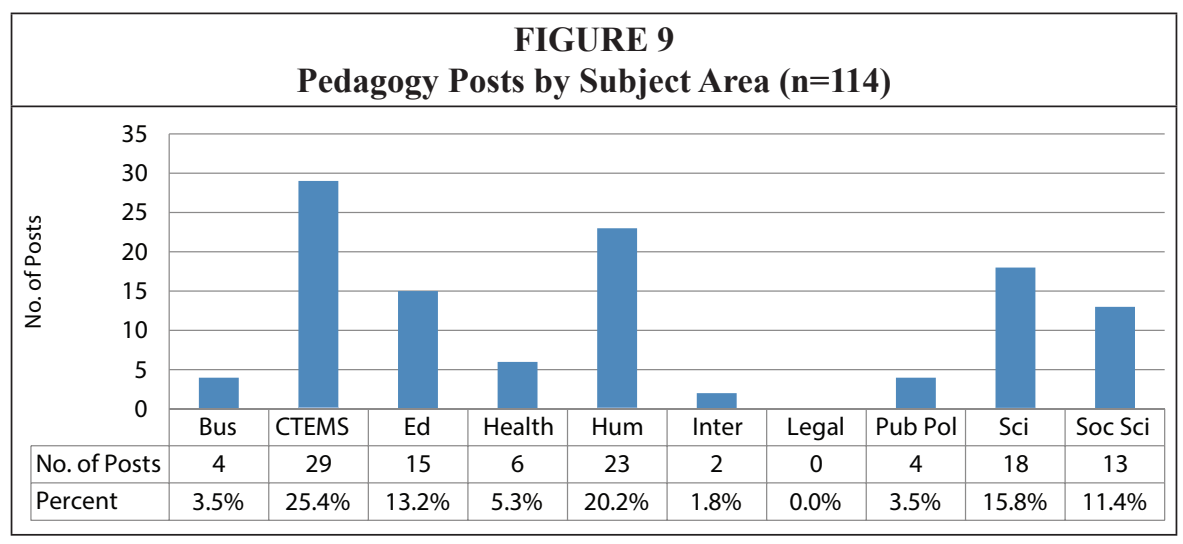

journals $(30.7 \%, \mathrm{n}=166)$, databases $(1.8 \%, \mathrm{n}=10)$, and general discussions about collection development issues $(0.74 \%, \mathrm{n}=4)$. Some posts also included information about books that had been nominated for awards, and information about older works still considered relevant by scholars and practitioners or assigned as required readings for courses that faculty were currently teaching.

Fewer still were posts coded to the Pedagogy category. Of the 47 associations with active social media accounts, only 29 associations posted information about new and emerging teaching practices or trends. The majority of the 114 posts were made by six associations: the American Historical Association (13.2\%, n=15), American Educational Research Association (9.6\%, $\mathrm{n}=11)$, Association for Computing Machinery $(7.9 \%, \mathrm{n}=9)$, American Statistical Association (7.0\%, n=8), American Geophysical Union (7.0\%, $\mathrm{n}=8)$, and American Physical Society $(6.1 \%, \mathrm{n}=7)$. By subject area, as shown in figure 9, CTEMS associations posted most of the messages coded to the Pedagogy category, followed by Humanities, Science, Education, Social Science, Health Science, Business \& Economics, Public Policy \& Administration, and Interdisciplinary Studies associations. No pedagogy-related posts were made by Legal Studies associations. Examples included information about teaching techniques and tools such as task-based learning, flipping the classroom, evidence-based teaching methods, student-centered teaching and learning, and topic-specific lesson plans.

The fewest number of posts were coded to the Technology category. By subject area, as shown in figure 10, Education associations posted the most information, followed by Science, Social Science, Health Science, CTEMS, Humanities, Business \& Economics, Legal Studies, and Public Policy \& Administration associations. No technology-

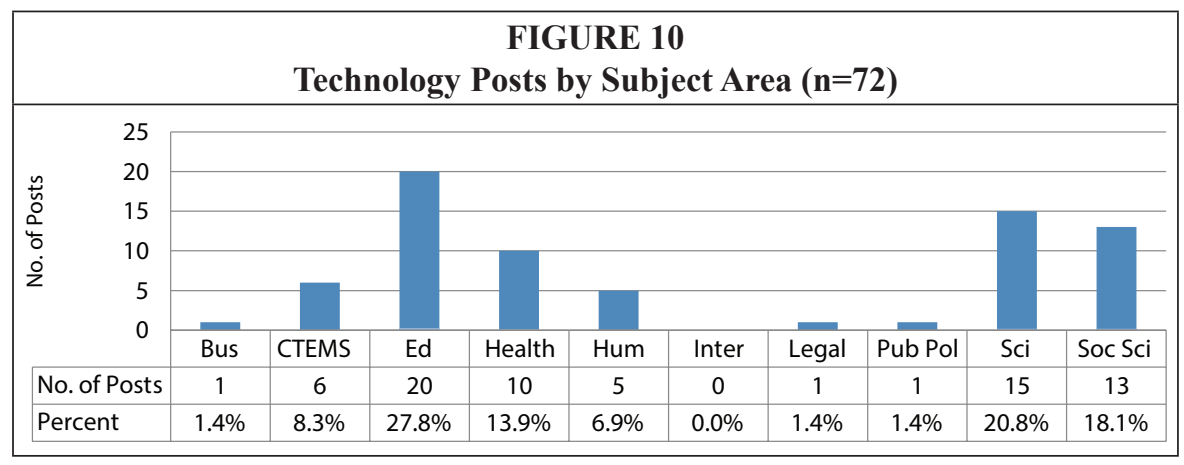


related posts were made by Interdisciplinary Studies. By association, the American Geophysical Union posted the most information to the Technology category $(13.9 \%$, $\mathrm{n}=10$ ), followed by the American Educational Research Association (9.7\%, n=7), American Anthropological Association (8.3\%, $\mathrm{n}=6$ ), and American Psychological Association, Association for Middle Level Education, and National Council of Teachers of English $(6.9 \%, n=5)$. Examples included information and discussions about subject-specific data analysis tools, data management systems, digital learning objects, social media sites, online resource-sharing projects, imaging tools, GIS technologies, digital scholarship resources, and discussions of open access issues and platforms. Specific examples included a post on essential apps for the mobile artist (College Art Association), a report on open access publishing (American Educational Research Association), a discussion on how digital technologies have changed the way historians conduct research (American Historical Association), a link to an animated interactive learning tool that examines the brains of mice on drugs (Society for Neuroscience), links to video games that teach anthropological concepts (American Anthropological Association), and a wiki created to help researchers locate anthropological source materials (American Anthropological Association).

An unexpected discovery, considering the inherent potential of the platform to disseminate content, was how few associations maintained a YouTube Channel and, of those that did, how infrequently the associations uploaded new videos. Of the 33 associations that had a YouTube account, only 19 (58\%) uploaded videos during the review period, most of which were posted by Science and Social Science associations. That being said, many of the associations that did not upload videos during the review period did post videos to their accounts before and after the review period. Associations with the most videos posted to their YouTube Channels overall included the American Geophysical Union ( $\mathrm{n}=182)$, American Mathematical Society $(\mathrm{n}=177)$, American Chemical Society ( $n=166)$, American Society for Microbiology ( $n=134)$, American Public Health Association $(n=120)$, American Society of Civil Engineers ( $n=105)$, and Society for Neuroscience $(n=61)$.

\section{Limitations}

There were a number of limitations to this study. First, it is acknowledged that the process by which the sampled associations were chosen was subjective and that a different set of associations and a larger sample size would likely produce different and more robust results. As this was an exploratory study, the subjective nature of the selection process was not considered detrimental to the overall results. Future research may be warranted to compare the results of a randomly chosen sample with the results of the current study. Second, although a concerted effort was made to locate the social media accounts of the sampled associations, it was difficult to ensure that all accounts were identified and included in the study. While the majority of associations provided links to all of the social media accounts they maintained via icons on their websites, there were a few associations that provided links to only some of their accounts or that did not provide links at all. In addition, some links were broken, while others linked to the social media platforms' home or signup page, but not to the actual accounts themselves. Furthermore, some associations maintained accounts that promoted their journal(s), an association resource, or current research, but not for news regarding the association or related discipline as a whole. For example, the American Economic Association and American Finance Association maintained Twitter accounts for the official journals of the associations, the Modern Language Association maintained a Facebook Page for the MLA International Bibliography but a Twitter account for MLA News, and the American Sociological Association 
maintained a YouTube Channel for the association's research department. As a result, information coded for these accounts was limited to their intended purpose, which made it difficult to compare the information with that of associations whose accounts included messages on a wider variety of topics. Moreover, some associations restricted LinkedIn Group membership to either current members of the association (IEEE: Institute of Electrical and Electronics Engineers, American Chemical Society, and American Society for Microbiology) or to degreed professionals currently employed in the discipline (American Society of Civil Engineers). Because the author was neither a member of these associations nor a degreed professional in their affiliated subject areas, messages posted by these Groups could not be coded and included in the results. These restrictions mirror those observed by Hankins et al. in their study of librarian attendance at subject-specific conferences. ${ }^{26}$ In addition, two associations (the American Finance Association and Latin American Studies Association) created their Facebook Pages during the review period (November 6, 2012, and December 12, 2012 , respectively), resulting in fewer posts that could be analyzed and coded. Other limitations included posts with broken links to external websites and links to articles and news items posted to password-protected association websites that only paid association members could access. Again, because these posts could not be viewed, they could not be coded and included in the results. Finally, it is important to note that the study provides only a brief snapshot into the sampled associations' use of social media. An expanded study may be needed to investigate scholarly association use of social media over a longer sampling period to provide a more thorough assessment of the types of information posted by associations that are applicable to a liaison librarian's job responsibilities. In addition, because the nature of social media is dynamic and always changing, collected data reflects only information posted to active accounts captured during the time period in which the results were coded. Posts that may have been deleted by account administrators or members before the posts could be coded are not included in the results.

\section{Conclusion}

Social media sites are increasingly being used by the scholarly community, including scholarly associations, to share information and exchange ideas. There is yet to be developed a body of literature, however, that explores how liaisons might use the information posted to the sites to increase their knowledge and improve their skills. The purpose of this study was to assess whether the information posted to the social media accounts of nonlibrary scholarly and professional associations could be used by liaisons as an efficient and timely method of staying current and informed in their assigned subject areas. The results of the study provide insights into the disciplines and associations that are using social media, the social media platforms that associations are using, the quantity and type of information that associations are posting, and the potential for liaisons to use the information as a way of staying up-to-date.

The results demonstrate that social media was used by the majority of the sampled associations during the designated period of the study to disseminate information, communicate, and engage in discussions with their members. Use of the social media platforms varied, however, with some associations and disciplines using the platforms more than others. The quantity and type of information posted also varied by association, by discipline, and by social media platform. As shown, most of the associations had a Facebook account. The majority of messages relevant to keeping a liaison informed, however, were posted to Twitter. In addition, when an association had both a Facebook and a Twitter account, in most instances, the messages posted to 
Facebook were duplicated on Twitter. Liaisons interested in using social media as a method of staying up-to-date would be advised, therefore, to concentrate their attention on Twitter when associations maintain accounts on both platforms. While all four platforms were used by associations to push content and information toward users, Twitter and LinkedIn were also used as a place for discussion. This was especially true of the LinkedIn Group accounts, which, for the most part, were used as a place for members to ask questions and engage in discussions with other members rather than as a place for the associations to disseminate information.

By discipline, associations in the Science, CTEMS, Health Science, Social Science, Humanities, and Education fields posted the most information coded as relevant to keeping a liaison informed and up-to-date. Public Policy \& Administration, Legal Studies, Business \& Economics, and Interdisciplinary Studies associations posted less information. Associations within these latter disciplines varied greatly, however, in the number of relevant posts made to the coded categories. For instance, as shown in appendix 3, two Business associations (the American Economic Association and American Finance Association), one Interdisciplinary Studies association (the Association for Asian American Studies), and one Public Policy \& Administration association (the Association for Public Policy Analysis and Management) posted a relatively high number of posts relevant to the Research Trends category. Hence, despite the low number of posts within these subject areas overall, liaisons whose subject assignments are affiliated with these associations might find it beneficial to monitor the social media posts made by them to improve their knowledge of current and emerging research trends. By category, for most of the disciplines represented in the study, the majority of relevant information was coded to the Subject Knowledge, Research Trends, and Current Events categories. ${ }^{27}$ Liaisons would seemingly gain the most information by monitoring the social media posts of scholarly associations in these three areas. The fewest number of posts were made to the Collection Development, Pedagogy, and Technology categories. ${ }^{28}$

While the study provides insight into the disciplines, associations, number, and types of messages posted to the associations' accounts, it does not evaluate the quality or value of the posted information for keeping a liaison up-to-date. The study also does not compare the information posted to the associations' accounts to the information that can be obtained through the traditional communication channels used by associations, such as the channels available exclusively to paid members, by attending the associations' affiliated conferences, or by reading the associations' official publications. The results of the current study suggest, however, that the posts made to the association accounts can serve as a beneficial supplement to the information gathered through more traditional methods. One of the primary benefits of using social media to stay current is that it allows liaisons to participate in and learn from a community of scholars from both within and outside a particular discipline. Since many associations allow anyone to follow or become a member of their social media pages, the sites allow liaisons to learn from scholars who may not be members of the association and hence not active on the communication channels reserved for paid members. These scholars may provide valuable insights that liaisons can use to improve their knowledge and their skills and hence better serve the departments to which they are assigned. For gaining and maintaining subject knowledge, the sites allow liaisons to receive information about the most current news and developments in a field in a timelier manner than might be achieved through more traditional methods. The sites also allow liaisons to read discussions and learn about the most recent and significant research deemed important by the associations and, perhaps more important, the scholars who post to the sites. In this way the sites 
act as a filtering device, directing liaisons to the most significant research conducted in a field, thereby reducing the time a liaison may need to spend sorting through the vast amount of literature that is published in some disciplines. As reported by Anatoliy Gruzd and Melissa Goertzen in their study on how social science scholars are using social media, "given the fact that publication overload is one of the major concerns faced by scholars," the need to gather and filter relevant information is becoming "increasingly important." 29 Additional benefits of using social media to staying informed and up-to-date include the ability to read discussions about new and important journals, databases, and monographs, including older monographs still considered relevant by scholars; the ability to read discussions and learn about the ways in which current events affect the discipline and the research conducted within the discipline; and the ability to become acquainted with and learn from new, upcoming, and prominent scholars in the field.

With regard to the last point, in addition to associations, individual scholars are increasingly using social media, especially blogs and Twitter, as a form of professional communication..$^{30}$ Observations conducted by the author during the course of the current study indicate that scholars are using their social media accounts to publicize their work, discuss issues within their discipline, publicize new and interesting research, engage in discussions with other researchers, comment on current events, and share personal information. ${ }^{31}$ The benefit of monitoring the social media accounts of individual scholars, including the posts these scholars make to association accounts, is that the posts can familiarize liaisons with the research and viewpoints of some of the more prominent scholars in the various disciplines. The posts made by these scholars to their blogs and other social media accounts often provide in-depth analysis and commentary on current issues and concerns within academia as a whole and the scholars' respective fields of study. Some scholars even post their research data and findings to their blogs. ${ }^{32}$ In addition, the information and citations shared by scholars on social media often provide insights into research between scholars of disparate disciplines. As observed by Jason Priem and Kaitlin Light Costello, "because scholars on Twitter typically follow people both in and out of their particular subfields, the conversations and the citations [to articles] that accompany them often afford a more interdisciplinary perspective." 33

Advantages of using social media aside, traditional methods that associations use to communicate via channels available only to those who become members and/or attend the associations' affiliated conferences provide liaisons with information that may not be readily available through the monitoring of social media accounts of either associations or scholars. For example, benefits provided to members of many of the sampled associations in the current study include access to online newsletters, discussion lists, forums, and blogs; webinars and online learning centers for professional development; annual reviews of research; information on grants and fellowships; databases of scholars' research interests; unpublished research paper repositories; subscriptions to official association journals and magazines; and conference proceedings. Liaisons who can afford to travel to association-affiliated conferences can attend presentations on the latest research, interact with scholars face-to-face, and learn about and hold discussions with publishers regarding new and forthcoming monographs. Although a comparison of these benefits to those provided by monitoring the social media accounts of associations is beyond the scope of the current study, preliminary insights gleaned by the author indicate that the monitoring of association social media accounts would serve to complement rather than replace the traditional mechanisms for information sharing sponsored by scholarly associations. Future research is needed, however, to more fully determine the degree to which the 
information obtained by monitoring the social media sites of associations would be useful to liaisons within specific subject areas as a way of staying up-to-date. Future research may also be warranted to more fully examine how the information shared by leading scholars on social media can help liaisons stay informed and how that information compares with the information posted to the social media accounts of scholarly associations.

Obstacles for using social media identified by the author during the course of the study included associations that require a degree, professional employment in the discipline, or association membership to join the associations' affiliated social media accounts; the difficulty in finding accounts for associations that do not link to them from their websites; links to association-related web pages that only association members can access; broken links to online articles; links to articles in subscriptionbased databases to which a liaison's home library may not subscribe; and the high volume of irrelevant messages posted by some associations. Nevertheless, as liaisons assume new roles and take on new and sometimes unfamiliar responsibilities, it becomes increasingly important for liaisons to use every viable method to develop their skills and increase their knowledge to better serve the faculty and students of the departments to which they are assigned. The results of this exploratory study indicate that the information posted to the social media accounts of scholarly associations has the potential to be used as a timely supplement to more traditional methods of staying current in the areas of subject knowledge, research trends, current events, and the latest information regarding association news and activities, most notably in the CTEMS, Health Science, Social Science, Humanities, and Education fields. The information obtained could be especially beneficial to liaisons that may not be able to afford the costs of membership in scholarly associations and attendance at scholarly conferences, however, future research is needed, as previously indicated, to more fully investigate the value of the posted information to a liaison librarian's job responsibilities. 


\begin{tabular}{|c|c|c|c|c|c|}
\hline \multicolumn{6}{|c|}{$\begin{array}{c}\text { APPENDIX A } \\
\text { Active Accounts by Social Media Platform and Association }\end{array}$} \\
\hline Subject Area & Name of Association & Facebook & LinkedIn & Twitter & YouTube \\
\hline \multirow[t]{5}{*}{ Business } & Academy of Management & $\checkmark$ & $\checkmark$ & $\checkmark$ & $\checkmark$ \\
\hline & Academy of Marketing Science & $\checkmark$ & $\checkmark$ & $\checkmark$ & $\checkmark$ \\
\hline & American Accounting Association & $\checkmark$ & $\checkmark$ & $\checkmark$ & \\
\hline & American Economic Association & & & $\checkmark$ & \\
\hline & American Finance Association & $\checkmark$ & $\checkmark$ & $\checkmark$ & \\
\hline \multirow[t]{5}{*}{ CTEMS } & American Mathematical Society & $\checkmark$ & $\checkmark$ & $\checkmark$ & $\checkmark$ \\
\hline & American Society of Civil Engineers & $\checkmark$ & $\checkmark$ & $\checkmark$ & $\checkmark$ \\
\hline & American Statistical Association & $\checkmark$ & $\checkmark$ & $\checkmark$ & \\
\hline & Association for Computing Machinery & $\checkmark$ & $\checkmark$ & $\checkmark$ & $\checkmark$ \\
\hline & IEEE: Institute of Electrical and Electronics Engineers & $\checkmark$ & $\checkmark$ & $\checkmark$ & $\checkmark$ \\
\hline \multirow[t]{5}{*}{ Education } & American Educational Research Association & $\checkmark$ & $\checkmark$ & $\checkmark$ & $\checkmark$ \\
\hline & Association for Middle Level Education & $\checkmark$ & $\checkmark$ & $\checkmark$ & $\checkmark$ \\
\hline & International Reading Association & $\checkmark$ & $\checkmark$ & $\checkmark$ & $\checkmark$ \\
\hline & National Council of Teachers of English & $\checkmark$ & $\checkmark$ & $\checkmark$ & $\checkmark$ \\
\hline & Society of Health and Physical Educators & $\checkmark$ & & $\checkmark$ & $\checkmark$ \\
\hline \multirow[t]{5}{*}{ Health Sciences } & American Medical Association & $\checkmark$ & $\checkmark$ & $\checkmark$ & $\checkmark$ \\
\hline & American Nurses Association & $\checkmark$ & $\checkmark$ & $\checkmark$ & $\checkmark$ \\
\hline & American Physical Therapy Association & $\checkmark$ & $\checkmark$ & $\checkmark$ & $\checkmark$ \\
\hline & American Physiological Society & $\checkmark$ & $\checkmark$ & $\checkmark$ & $\checkmark$ \\
\hline & American Public Health Association & $\checkmark$ & $\checkmark$ & & $\checkmark$ \\
\hline
\end{tabular}




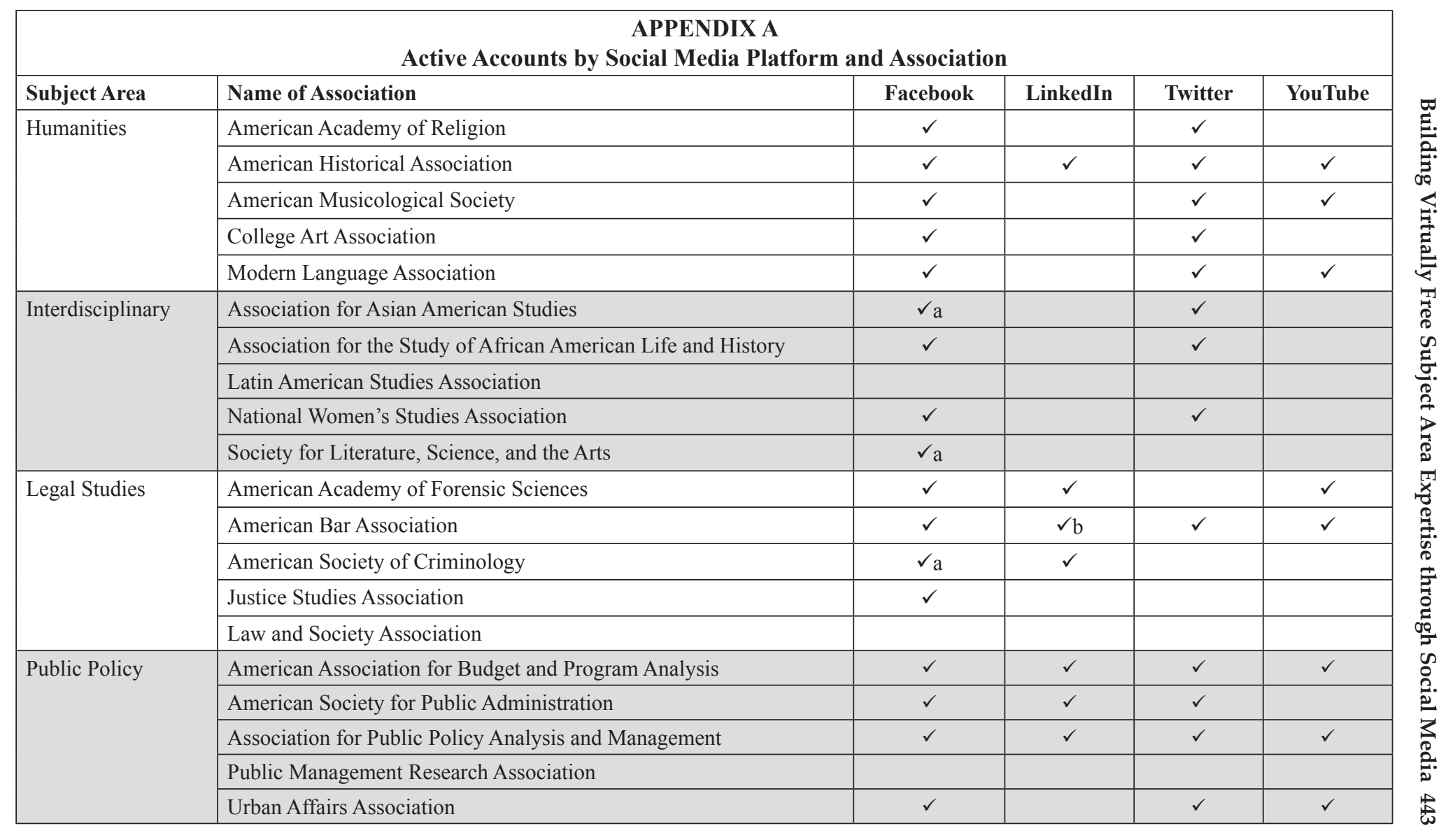




\begin{tabular}{|c|c|c|c|c|c|}
\hline \multicolumn{6}{|c|}{$\begin{array}{c}\text { APPENDIX A } \\
\text { Active Accounts by Social Media Platform and Association }\end{array}$} \\
\hline Subject Area & Name of Association & Facebook & LinkedIn & Twitter & YouTube \\
\hline \multirow[t]{4}{*}{ Sciences } & American Chemical Society & $\checkmark$ & $\checkmark$ & $\checkmark$ & $\checkmark$ \\
\hline & American Geophysical Union & $\checkmark$ & $\checkmark$ & $\checkmark$ & $\checkmark$ \\
\hline & American Physical Society & $\checkmark$ & $\checkmark$ & $\checkmark$ & $\checkmark$ \\
\hline & American Society for Microbiology & $\checkmark$ & $\checkmark$ & $\checkmark$ & $\checkmark$ \\
\hline \multirow[t]{5}{*}{ Social Sciences } & American Anthropological Association & $\checkmark$ & $\checkmark$ & $\checkmark$ & \\
\hline & American Political Science Association & $\checkmark$ & $\checkmark$ & $\checkmark$ & $\checkmark$ \\
\hline & American Psychological Association & $\checkmark$ & $\checkmark$ & $\checkmark$ & $\checkmark$ \\
\hline & American Sociological Association & $\checkmark$ & $\checkmark$ & $\checkmark$ & $\checkmark$ \\
\hline & National Communication Association & $\checkmark$ & & $\checkmark$ & $\checkmark$ \\
\hline
\end{tabular}




\begin{tabular}{|c|c|c|c|c|c|c|}
\hline \multicolumn{7}{|c|}{$\begin{array}{c}\text { APPENDIX B } \\
\text { Number of Relevant Posts per Social Media Platform by Association }\end{array}$} \\
\hline Subject Area & Name of Association & Facebook & LinkedIn & Twitter & YouTube & $\begin{array}{c}\text { Total Posts } \\
\text { per Assn. }\end{array}$ \\
\hline \multirow[t]{5}{*}{ Business } & Academy of Management & 13 & 9 & 40 & 4 & 66 \\
\hline & Academy of Marketing Science & 5 & 12 & 7 & 0 & 24 \\
\hline & American Accounting Association & 3 & 12 & 5 & $0 \mathrm{a}$ & 20 \\
\hline & American Economic Association & $0 \mathrm{a}$ & $0 \mathrm{a}$ & 69 & $0 \mathrm{a}$ & 69 \\
\hline & American Finance Association & 9 & $0 \mathrm{c}$ & 64 & $0 \mathrm{a}$ & 73 \\
\hline \multirow[t]{5}{*}{ CTEMS } & American Mathematical Society & 18 & 105 & 86 & 5 & 214 \\
\hline & American Society of Civil Engineers & 14 & $0 \mathrm{~b}$ & 573 & 4 & 591 \\
\hline & American Statistical Association & 18 & 6 & 227 & $0 \mathrm{a}$ & 251 \\
\hline & Association for Computing Machinery & 8 & 26 & 89 & 0 & 123 \\
\hline & IEEE: Institute of Electrical and Electronics Engineers & 25 & $0 \mathrm{~b}$ & 405 & 0 & 430 \\
\hline \multirow[t]{5}{*}{ Education } & American Educational Research Association & 21 & 35 & 102 & 23 & 181 \\
\hline & Association for Middle Level Education & 18 & 7 & 132 & 1 & 158 \\
\hline & International Reading Association & 12 & 16 & 139 & 1 & 168 \\
\hline & National Council of Teachers of English & 17 & 16 & 189 & 22 & 244 \\
\hline & Society of Health and Physical Educators & 5 & $0 \mathrm{a}$ & 25 & 0 & 30 \\
\hline \multirow[t]{5}{*}{ Health Sciences } & American Medical Association & 38 & 158 & 466 & 5 & 667 \\
\hline & American Nurses Association & 14 & 132 & 21 & 3 & 170 \\
\hline & American Physical Therapy Association & 18 & 15 & 187 & 33 & 253 \\
\hline & American Physiological Society & 14 & $0 \mathrm{c}$ & 41 & 0 & 55 \\
\hline & American Public Health Association & 39 & 151 & $0 \mathrm{a}$ & 12 & 202 \\
\hline
\end{tabular}




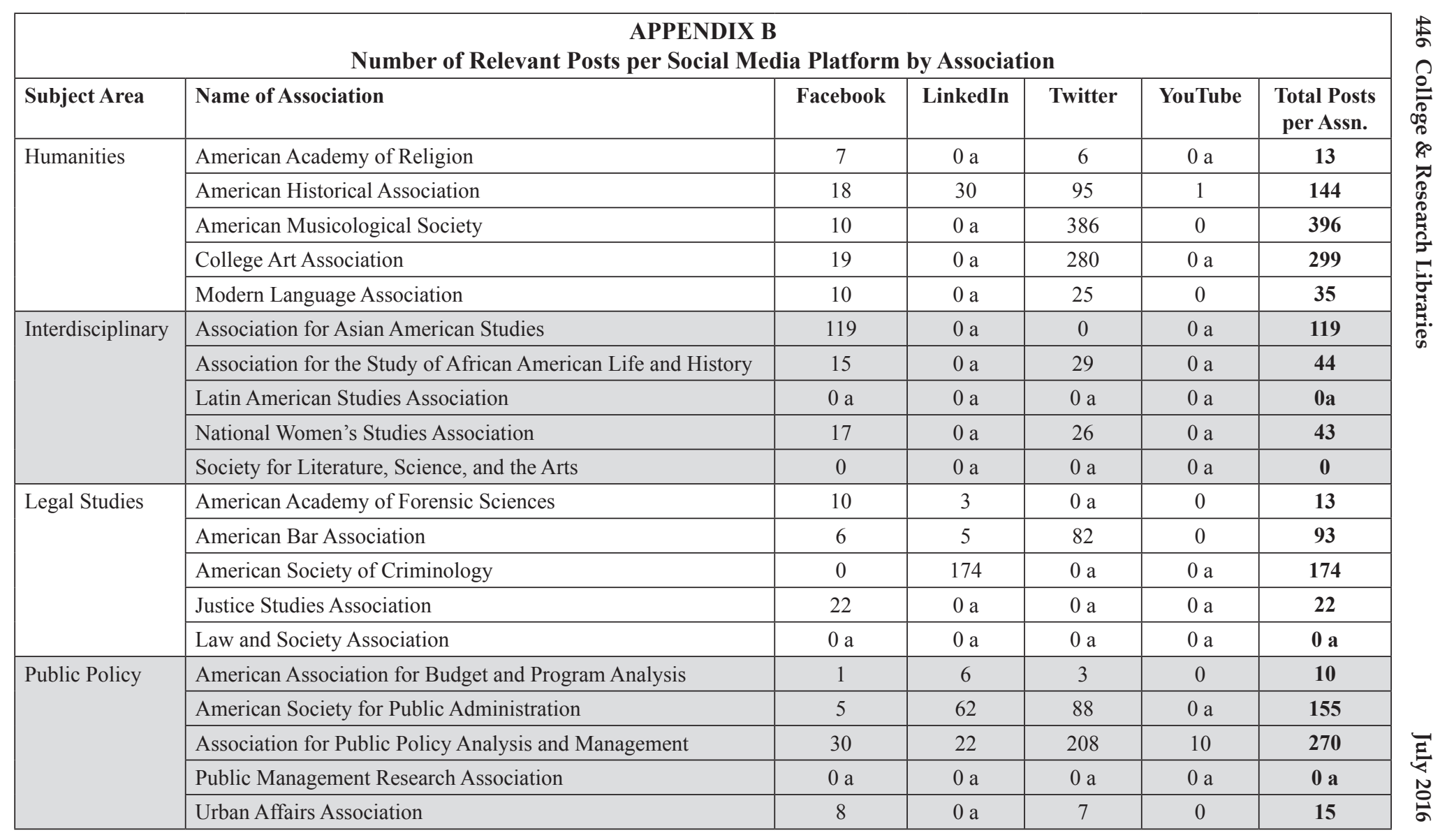




\begin{tabular}{|c|c|c|c|c|c|c|}
\hline \multicolumn{7}{|c|}{$\begin{array}{c}\text { APPENDIX B } \\
\text { Number of Relevant Posts per Social Media Platform by Association }\end{array}$} \\
\hline Subject Area & Name of Association & Facebook & LinkedIn & Twitter & YouTube & $\begin{array}{c}\text { Total Posts } \\
\text { per Assn. }\end{array}$ \\
\hline \multirow{3}{*}{ Sciences } & American Geophysical Union & 324 & 158 & 341 & 143 & 966 \\
\hline & American Physical Society & 17 & 60 & 411 & 6 & 494 \\
\hline & Society for Neuroscience & 30 & 148 & 126 & 5 & 309 \\
\hline \multirow[t]{4}{*}{ Social Sciences } & American Anthropological Association & 25 & 143 & 131 & $0 \mathrm{a}$ & 299 \\
\hline & American Political Science Association & 19 & 1 & 40 & 0 & 60 \\
\hline & American Psychological Association & 30 & 54 & 371 & 20 & 475 \\
\hline & American Sociological Association & 21 & 70 & 68 & 0 & 159 \\
\hline \multicolumn{7}{|c|}{$\begin{array}{l}\mathrm{a}=\text { No account during the review period } \\
\mathrm{b}=\text { Unable to tally; membership restricted to members of the association or to degreed professionals } \\
\mathrm{c}=\text { Unable to tally; membership request never approved }\end{array}$} \\
\hline
\end{tabular}




\begin{tabular}{|c|c|c|c|c|c|c|c|c|c|c|}
\hline \multicolumn{10}{|c|}{$\begin{array}{c}\text { APPENDIX C } \\
\text { Number of Relevant Posts per Category by Association }\end{array}$} & \\
\hline Subject Area & Name of Association & $\begin{array}{l}\text { Association } \\
\text { Information }\end{array}$ & $\begin{array}{c}\text { Collection } \\
\text { Development }\end{array}$ & $\begin{array}{c}\text { Current } \\
\text { Events }\end{array}$ & Pedagogy & $\begin{array}{c}\text { Research } \\
\text { Trends }\end{array}$ & $\begin{array}{c}\text { Subject } \\
\text { Knowledge }\end{array}$ & Technology & $\begin{array}{l}\text { Total Posts } \\
\text { per Assn. }\end{array}$ & \\
\hline \multirow[t]{5}{*}{ Business } & Academy of Management & 14 & 8 & 10 & 3 & 25 & 5 & 1 & 66 & \\
\hline & Academy of Marketing Science & 17 & 0 & 0 & 1 & 6 & 0 & 0 & 24 & \\
\hline & American Accounting Association & 5 & 1 & 0 & 0 & 3 & 11 & 0 & 20 & \\
\hline & American Economic Association & 0 & 0 & 0 & 0 & 69 & 0 & 0 & 69 & \\
\hline & American Finance Association & 5 & 1 & 0 & 0 & 66 & 1 & 0 & 73 & \\
\hline \multirow[t]{5}{*}{ CTEMS } & American Mathematical Society & 7 & 11 & 11 & 3 & 19 & 162 & 1 & 214 & \\
\hline & $\begin{array}{l}\text { American Society of Civil } \\
\text { Engineers }\end{array}$ & 19 & 2 & 42 & 3 & 2 & 522 & 1 & 591 & \\
\hline & American Statistical Association & 45 & 17 & 23 & 8 & 26 & 131 & 1 & 251 & \\
\hline & $\begin{array}{l}\text { Association for Computing } \\
\text { Machinery }\end{array}$ & 2 & 2 & 31 & 9 & 29 & 50 & 0 & 123 & \\
\hline & $\begin{array}{l}\text { IEEE: Institute of Electrical and } \\
\text { Electronics Engineers }\end{array}$ & 26 & 6 & 8 & 6 & 51 & 330 & 3 & 430 & \\
\hline \multirow[t]{5}{*}{ Education } & $\begin{array}{l}\text { American Educational Research } \\
\text { Association }\end{array}$ & 21 & 3 & 29 & 11 & 62 & 48 & 7 & 181 & \\
\hline & $\begin{array}{l}\text { Association for Middle Level } \\
\text { Education }\end{array}$ & 3 & 3 & 27 & 2 & 7 & 111 & 5 & 158 & \\
\hline & International Reading Association & 12 & 65 & 6 & 0 & 9 & 74 & 2 & 168 & \\
\hline & $\begin{array}{l}\text { National Council of Teachers of } \\
\text { English }\end{array}$ & 19 & 30 & 24 & 2 & 48 & 116 & 5 & 244 & \\
\hline & $\begin{array}{l}\text { Society of Health and Physical } \\
\text { Educators }\end{array}$ & 3 & 1 & 13 & 0 & 1 & 11 & 1 & 30 & \\
\hline
\end{tabular}




\begin{tabular}{|c|c|c|c|c|c|c|c|c|c|}
\hline \multirow{2}{*}{\multicolumn{10}{|c|}{ 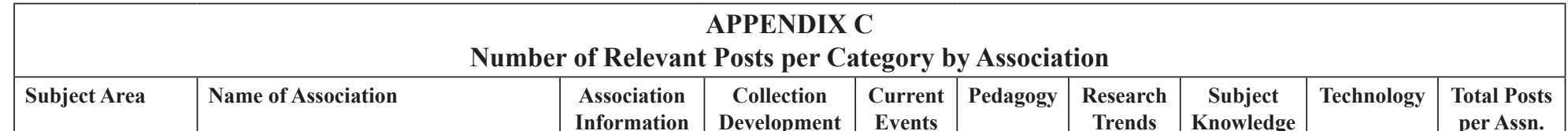 }} \\
\hline & & & & & & & & & \\
\hline \multirow[t]{5}{*}{ Health Sciences } & American Medical Association & 57 & 8 & 272 & 5 & 47 & 275 & 3 & 667 \\
\hline & American Nurses Association & 6 & 1 & 22 & 0 & 11 & 128 & 2 & 170 \\
\hline & $\begin{array}{l}\text { American Physical Therapy } \\
\text { Association }\end{array}$ & 24 & 3 & 44 & 0 & 38 & 143 & 1 & 253 \\
\hline & American Physiological Society & 8 & 4 & 0 & 0 & 32 & 11 & 0 & 55 \\
\hline & $\begin{array}{l}\text { American Public Health } \\
\text { Association }\end{array}$ & 9 & 6 & 43 & 1 & 62 & 77 & 4 & 202 \\
\hline \multirow[t]{5}{*}{ Humanities } & American Academy of Religion & 4 & 1 & 0 & 0 & 4 & 4 & 0 & 13 \\
\hline & American Historical Association & 11 & 8 & 15 & 15 & 17 & 76 & 2 & 144 \\
\hline & American Musicological Society & 42 & 137 & 0 & 0 & 188 & 29 & 0 & 396 \\
\hline & College Art Association & 28 & 63 & 14 & 6 & 41 & 145 & 2 & 299 \\
\hline & Modern Language Association & 14 & 1 & 0 & 2 & 5 & 12 & 1 & 35 \\
\hline \multirow[t]{5}{*}{ Interdisciplinary } & $\begin{array}{l}\text { Association for Asian American } \\
\text { Studies }\end{array}$ & 6 & 13 & 37 & 2 & 36 & 25 & 0 & 119 \\
\hline & $\begin{array}{l}\text { Association for the Study of } \\
\text { African American Life and } \\
\text { History }\end{array}$ & 16 & 5 & 11 & 0 & 5 & 7 & 0 & 44 \\
\hline & $\begin{array}{l}\text { Latin American Studies } \\
\text { Association }\end{array}$ & $0 \mathrm{a}$ & $0 \mathrm{a}$ & $0 \mathrm{a}$ & $0 \mathrm{a}$ & $0 \mathrm{a}$ & $0 \mathrm{a}$ & $0 \mathrm{a}$ & 0 a \\
\hline & $\begin{array}{l}\text { National Women's Studies } \\
\text { Association }\end{array}$ & 6 & 1 & 6 & 0 & 23 & 7 & 0 & 43 \\
\hline & $\begin{array}{l}\text { Society for Literature, Science, } \\
\text { and the Arts }\end{array}$ & 0 & 0 & 0 & 0 & 0 & 0 & 0 & $\mathbf{0}$ \\
\hline
\end{tabular}




\begin{tabular}{|c|c|c|c|c|c|c|c|c|c|}
\hline \multirow{2}{*}{\multicolumn{10}{|c|}{$\begin{array}{l}\text { APPENDIX C } \\
\text { Number of Relevant Posts per Category by Association } \\
\end{array}$}} \\
\hline Subject Area & & & & & & & & & \\
\hline \multirow[t]{5}{*}{ Legal Studies } & $\begin{array}{l}\text { American Academy of Forensic } \\
\text { Sciences }\end{array}$ & 2 & 0 & 2 & 0 & 1 & 8 & 0 & 13 \\
\hline & American Bar Association & 3 & 8 & 31 & 0 & 1 & 50 & 0 & 93 \\
\hline & American Society of Criminology & 8 & 5 & 120 & 0 & 8 & 32 & 1 & 174 \\
\hline & Justice Studies Association & 2 & 2 & 2 & 0 & 3 & 13 & 0 & 22 \\
\hline & Law and Society Association & $0 \mathrm{a}$ & $0 \mathrm{a}$ & $0 \mathrm{a}$ & $0 \mathrm{a}$ & $0 \mathrm{a}$ & $0 \mathrm{a}$ & $0 \mathrm{a}$ & 0 a \\
\hline \multirow[t]{5}{*}{ Public Policy } & $\begin{array}{l}\text { American Association for Budget } \\
\text { and Program Analysis }\end{array}$ & 4 & 0 & 0 & 0 & 1 & 5 & 0 & 10 \\
\hline & $\begin{array}{l}\text { American Society for Public } \\
\text { Administration }\end{array}$ & 15 & 3 & 26 & 2 & 9 & 99 & 1 & 155 \\
\hline & $\begin{array}{l}\text { Association for Public Policy } \\
\text { Analysis and Management }\end{array}$ & 17 & 9 & 34 & 2 & 138 & 70 & 0 & 270 \\
\hline & $\begin{array}{l}\text { Public Management Research } \\
\text { Association }\end{array}$ & $0 \mathrm{a}$ & $0 \mathrm{a}$ & $0 \mathrm{a}$ & $0 \mathrm{a}$ & $0 \mathrm{a}$ & $0 \mathrm{a}$ & $0 \mathrm{a}$ & 0 a \\
\hline & Urban Affairs Association & 1 & 0 & 1 & 0 & 1 & 12 & 0 & 15 \\
\hline \multirow[t]{5}{*}{ Sciences } & American Chemical Society & 3 & 0 & 2 & 1 & 3 & 64 & 0 & 73 \\
\hline & American Geophysical Union & 45 & 5 & 181 & 8 & 414 & 303 & 10 & 966 \\
\hline & American Physical Society & 5 & 3 & 33 & 7 & 252 & 192 & 2 & 494 \\
\hline & $\begin{array}{l}\text { American Society for } \\
\text { Microbiology }\end{array}$ & 1 & 8 & 8 & 0 & 50 & 71 & 1 & 139 \\
\hline & Society for Neuroscience & 14 & 5 & 15 & 2 & 102 & 169 & 2 & 309 \\
\hline
\end{tabular}




\begin{tabular}{|c|c|c|c|c|c|c|c|c|c|}
\hline \multicolumn{10}{|c|}{$\begin{array}{c}\text { APPENDIX C } \\
\text { Number of Relevant Posts per Category by Association }\end{array}$} \\
\hline Subject Area & Name of Association & $\begin{array}{l}\text { Association } \\
\text { Information }\end{array}$ & $\begin{array}{c}\text { Collection } \\
\text { Development }\end{array}$ & $\begin{array}{c}\text { Current } \\
\text { Events }\end{array}$ & Pedagogy & $\begin{array}{l}\text { Research } \\
\text { Trends }\end{array}$ & $\begin{array}{c}\text { Subject } \\
\text { Knowledge }\end{array}$ & Technology & $\begin{array}{l}\text { Total Posts } \\
\text { per Assn. }\end{array}$ \\
\hline \multirow{3}{*}{ Social Sciences } & $\begin{array}{l}\text { American Political Science } \\
\text { Association }\end{array}$ & 28 & 2 & 5 & 1 & 14 & 10 & 0 & 60 \\
\hline & $\begin{array}{l}\text { American Sociological } \\
\text { Association }\end{array}$ & 11 & 10 & 17 & 3 & 45 & 71 & 2 & 159 \\
\hline & $\begin{array}{l}\text { National Communication } \\
\text { Association }\end{array}$ & 9 & 47 & 14 & 3 & 42 & 12 & 0 & 127 \\
\hline
\end{tabular}

$\mathrm{a}=$ No accounts during the review period 


\section{Notes}

1. For one of the earliest discussions of the liaison model, see: Laurence Miller, "Liaison Work in the Academic Library," RQ 16, no. 3 (Spring 1977): 213-15.

2. Susan Logue, John Ballestro, Andrea Imre, and Julie Arendt, SPEC Kit 301: Liaison Services (Washington D.C.: Association of Research Services, 2007).

3. Janice M. Jaguszewski and Karen Williams, New Roles for New Times: Transforming Liaison Roles in Research Libraries (Washington, D.C.: Association of Research Libraries, 2013), 4-12, available online at www.arl.org/storage/documents/publications/NRNT-Liaison-Roles-final.pdf [accessed 15 September 2014].

4. Stephanie H. Crowe and Janice M. Jaguszewski, "Preparing Our Librarians for the Future: Identifying and Assessing Core Competencies at the University of Minnesota Libraries," in The Expert Library: Staffing, Sustaining, and Advancing the Academic Library in the 21st Century, eds. Scott Walter and Karen Williams (Chicago: Association of College and Research Libraries, 2010), 127-38; Linda Daniel, Jean Ferguson, Teddy Gray, Aisha Harvey, Diane Harvey, Danette Pachtner, and Kristina Troost, "Engaging with Library Users: Sharpening Our Vision as Subject Librarians for the Duke University Libraries," Duke University Libraries, January 14, 2001, available online at http://library.duke.edu/sites/default/files/dul/about/subject-librarian-report-2011.pdf [accessed 11 April 2015].

5. Association of Research Libraries, Coalition for Networked Information, and the Scholarly Publishing and Academic Resources Coalition, "Research Library Issues, no. 265 (Aug. 2009): Special Issue on Liaison Librarian Roles," available online at http://publications.arl.org/rli265/ [accessed 15 September 2014]; Crowe and Jaguszewski, "Preparing Our Librarians for the Future," 127-38; Lisa Federer, Exploring New Roles for Librarians: The Research Informationist (San Rafael, Calif.: Morgan \& Claypool Publishers, 2014); Gary Freiburger and Sandra Kramer, "Embedded Librarians: One Library's Model for Decentralized Service," Journal of the Medical Library Association 97, no. 2 (Apr. 2009): 139-41, doi:10.3163/1536-5050.97.2.013; Craig Gibson and Jamie Wright Coniglio, "The New Liaison Librarian: Competencies for the 21st Century Academic Library," in The Expert Library: Staffing, Sustaining, and Advancing the Academic Library in the 21st Century, eds. Scott Walter and Karen Williams (Chicago: Association of College and Research Libraries, 2010) 107-13; Brenna Helmstutler, "New Research Portal for Faculty," Georgia State University Library Blog (Aug. 23, 2013), available online at http://homer.gsu.edu/blogs/library/2013/08/23/ new-research-portal-for-faculty-2/ [accessed 15 September 2014]; Interdisciplinarity \& Academic Libraries, eds. Daniel C. Mack and Craig Gibson (Chicago: Association of College \& Research Libraries, 2012); The New Academic Librarian: Essays on Changing Roles and Responsibilities, eds. Rebeca Peacock and Jill Wurm (Jefferson, N.C.: McFarland \& Company, Inc., Publishers, 2013); Gary W. White, "Professional Development of Liaison Librarians: Fostering Skills for the Twenty-First Century," in Assessing Liaison Librarians: Documenting Impact for Positive Change, eds. Daniel C. Mack and Gary W. White (Chicago: Association of College and Research Libraries, 2014), 121-37.

6. Miranda Henry Bennett, "The Benefits of Non-Library Professional Organization Membership for Liaison Librarians," Journal of Academic Librarianship 37, no. 1 (Jan. 2011): 46-53, doi:10.1016/j.acalib.2010.10.006; Rebecca Blakiston, "Building Knowledge, Skills, and Abilities: Continual Learning in the New Information Landscape," Journal of Library Administration 51, no. 7/8 (Oct.-Dec. 2011): 728-43, doi:10.1080/01930826.2011.601272; Tara Tobin Cataldo, Michele R. Tennant, Pamela Sherwill-Navarro, and Rae Jesano, "Subject Specialization in a Liaison Librarian Program," Journal of the Medical Library Association 94, no. 4 (Oct. 2006): 446-48; Lucy Eleonore Lyons, "The Dilemma for Academic Librarians with Collection Development Responsibilities: A Comparison of the Value of Attending Library Conferences Versus Academic Conferences," Journal of Academic Librarianship 33, no. 2 (Mar. 2007): 180-89, doi:10.1016/j.acalib.2006.12.001; Rebecca Hankins, Pauline Melgoza, Christina Seeger, and Gary Wan, "Meeting Our Users Where They Conference: A Texas A\&M Model to Support Librarian Attendance at Subject-Specific Conferences," Public Services Quarterly 5, no. 2 (June 2009): 98-113, doi:10.1080/15228950902837541; Skye Hardesty and Tammy Sugarman, "Academic Librarians, Professional Literature, and New Technologies: A Survey," Journal of Academic Librarianship 33, no. 2 (Mar. 2007): 196-205, doi:10.1016/j. acalib.2006.12.006; Robert Tomaszewski and Karen I. MacDonald, "Identifying Subject-Specific Conferences as Professional Development Opportunities for the Academic Librarian," Journal of Academic Librarianship 35, no. 6 (Nov. 2009): 583-90, doi:10.1016/j.acalib.2009.08.006; Cynthia Tysick, "Attending Conferences Outside of Librarianship," College \& Undergraduate Libraries 9, no. 2 (2002): 75-81, doi: 0.1300/J106v09n02_08.

7. Hardesty and Sugarman, "Academic Librarians, Professional Literature, and New Technologies," 196-205.

8. Ibid., 202. 


\section{Building Virtually Free Subject Area Expertise through Social Media 453}

9. Ibid., 201.

10. Kaetrena Davis Kendrick, Echo Leaver, and Debora Tritt, "Link Up the Sticks: Access and Barriers to Professional Development for Small and Rural Academic Librarians," Codex: Journal of the Louisiana Chapter of the ACRL 2, no. 3 (2013): 38-77.

11. Christopher Hooper-Lane, "Spotlight on the Subject Knowledge of Chemistry Librarians: Results of a Survey," Issues in Science and Technology Librarianship (Summer 1999): 1-9, available online at www.istl.org/99-summer/article1.html [accessed 15 September 2014].

12. Erin M. Watson, "Subject Knowledge in the Health Sciences Library: An Online Survey of Canadian Academic Health Sciences Librarians," Journal of the Medical Library Association 93, no. 4 (Oct. 2005): 459-66; Erin M. Watson, "The Role of Subject Knowledge in Academic Health Sciences Libraries: An Online Survey of Librarians Working in the United States," Journal of the Canadian Health Libraries Association 29, no. 1 (2008): 3-11.

13. For instance, Rachel Harrison, "Unique Benefits of Conference Attendance as a Method of Professional Development for LIS Professionals," Serials Librarian 59, no. 3/4 (Oct.-Dec. 2010): 263-70, doi:10.1080/0361526X.2010.489353; Tomaszewski and MacDonald, "Identifying SubjectSpecific Conferences," 583-90; Tysick, "Attending Conferences Outside of Librarianship," 75-81.

14. Bennett, "The Benefits of Non-Library Professional Organization Membership," 46-53.

15. Hankins et al., "Meeting Our Users Where They Conference," 98-113; Lyons, "The Dilemma for Academic Librarians," 180-89.

16. Hankins et al., "Meeting Our Users Where They Conference," 109.

17. Lyons, "The Dilemma for Academic Librarians," 185.

18. Lyons, "The Dilemma for Academic Librarians," 186.

19. Nicole A. Cooke, "Professional Development 2.0 for Librarians: Developing an Online Personal Learning Network (PLN)," Library Hi Tech News 3 (Apr. 2012): 1-9, doi:10.1108/07419051211241840; Michelle Dalton, "What Would I Tweet? Exploring New Professionals' Attitudes Towards Twitter as a Tool for Professional Development," Journal of Library Innovation 4, no. 2 (2013): 101-10; Vanessa DiMauro, "Using Online Communities in Professional Associations," Information Outlook 15, no. 4 (June 2011): 18-20; Anne Marie Gruber, "Wired Professional Development: New Librarians Connect Through the Web," College \& Undergraduate Libraries 14, no. 4 (2007): 95-102, doi:10.1080/10691310802128377; Marianne Lenox and Maurice Coleman, "Using Social Networks to Create Powerful Learning Communities," Computers in Libraries 30, no. 7 (Sept. 2010): 13-17; Kevin Stranack, "The Connected Librarian: Using Social Media for ‘Do It Yourself' Professional Development," Partnership: The Canadian Journal of Library \& Information Practice \& Research 7, no. 1 (2012): 1-5.

20. Due to space limitations, these categories will be abbreviated in some of the tables and figures in the following ways: Business: Business or Bus; Computer Science, Technology, Engineering, Mathematics, and Statistics: CTEMS; Education: Ed; Health Sciences: Health; Humanities: Hum; Interdisciplinary Studies: Interdisciplinary or Inter; Legal Studies: Legal; Public Policy and Administration: Public Policy or Pub Pol; Sciences: Sci; Social Sciences: Soc Sci.

21. For a discussion of the history of scholarly associations, see James Hopkins, "The Role of Learned Societies in Knowledge Exchange and Dissemination: The Case of the Regional Studies Association, 1965-2005," History of Education 40, no. 2 (Mar. 2011): 259-60, doi:10.1080/00467 60X.2010.518161. See also "The Work of the Societies," American Council of Learned Societies, 2014, available online at https://www.acls.org/societies/work.aspx?id=1264 [accessed 8 July 2014].

22. See https://www.quantcast.com.

23. This is to say that the data was collected and coded after the fact, rather than in real time or as the information was added to the accounts. Collecting and coding the data in real time would have been too cumbersome, as it would have required all fifty of the social media accounts included in the study to be monitored simultaneously.

24. Twitter now allows videos to be embedded into posts, but it was not allowed during the time period of the study.

25. Ryan K. Boettger and Laura A. Palmer, “Quantitative Content Analysis: Its Use in Technical Communication," IEEE Transactions on Professional Communication 53, no. 4 (Dec. 2010): 346, doi:10.1109/TPC.2010.2077450.

26. Hankins et al., "Meeting Our Users Where They Conference," 109.

27. Exceptions included Legal Studies associations, which posted few messages regarding current research; Business \& Economics associations, which posted few messages regarding subject knowledge and current events; and Humanities associations, which posted few messages regarding current events.

28. Exceptions included Humanities, Education, and Social Science associations, which posted a relatively high number of collection development posts as compared to other associations.

29. Anatoliy Gruzd and Melissa Goertzen, "Wired Academia: Why Social Science Scholars Are Using Social Media," Proceedings of the 46th Hawaii International Conference on System Sciences 
(HICSS), (Jan. 4-7, 2013): 3332-41, doi:10.1109/HICSS.2013.614.

30. Examples of prominent scholars using social media for professional work in the form of blogs and/or Twitter include Clayton Christensen (Business), Nassim Nicholas Taleb (Economics), Diane Ravitch (Education), Robert Reich (Legal Studies), Michael Berube (Literature/Cultural Studies), Daniel Dennett and Brian Leiter (Philosophy), Francis Fukuyama (Political Science), and Judith Weisenfeld (Religious Studies), to name just a few.

31. These findings mirror those of studies conducted on scholars' use of social media. For example, see: Gruzd and Goertzen, "Wired Academia," 3332-41; Jason Priem and Kaitlin Light Costello, "How and Why Scholars Cite on Twitter," Proceedings of the American Society for Information Science and Technology 47, no. 1 (Nov./Dec. 2010): 1-4, doi:10.1002/meet.14504701201; George Veletsianos, "Higher Education Scholars' Participation and Practices on Twitter," Journal of Computer Assisted Learning 28, no. 4 (Aug. 2012): 336-49, doi:10.1111/j.1365-2729.2011.00449x.

32. See, for example, Zen Faulkes, "The Distal Leg Motor Neurons of Slipper Lobsters, Ibacus Spp. (Decapoda, Scyllaridae)," NeuroDojo (Sept. 6, 2012), available online at http://neurodojo. blogspot.com/2012/09/Ibacus.html [accessed 3 January 2015].

33. Priem and Costello, "How and Why Scholars Cite on Twitter," 3. 